\title{
Leipalingio dvaro pastatų raida: žvalgomujụ architektūros tyrimų ir restauravimo duomenys
}

\section{Evaldas Purlys}

Projektavimo ir restauravimo institutas

Universiteto g. 4, LT-01122 Vilnius

Vilniaus dailès akademijos Paminklotvarkos katedra

Maironio g. 6, LT-01124 Vilnius

evaldas@pri.lt

\footnotetext{
Straipsnyje analizuojama Leipalingio dvaro rūmų ansamblio trijų pastatų - rūmų, oranžerijos ir grūdų sandèlio - architektūros raida, kuri geriausiai išryškèjo 2010-2014 m. ir 2019-2020 m. atliekant natūros tyrimus ir restauravimo darbus. Pastarieji kompensavo istorinių duomenų trūkumą apie ši ansamblì. Architektūrinių tyrimų rezultatų lyginimas su Leipalingio muziejuje saugomomis nuotraukomis atskleidè daug naujo apie dvaro pastatų architektūros ir dekoro elementų kaitą. Straipsnio autorius pats atliko žvalgomuosius architektūros tyrimus, todèl daugelis įžvalgų yra pastatų analizavimo natūroje rezultatas.
}

Reikšminiai žodžiai: Leipalingio dvaras (Druskininkų r.), architektūra, žvalgomieji architektūros tyrimai, paveldas, restauravimas. 


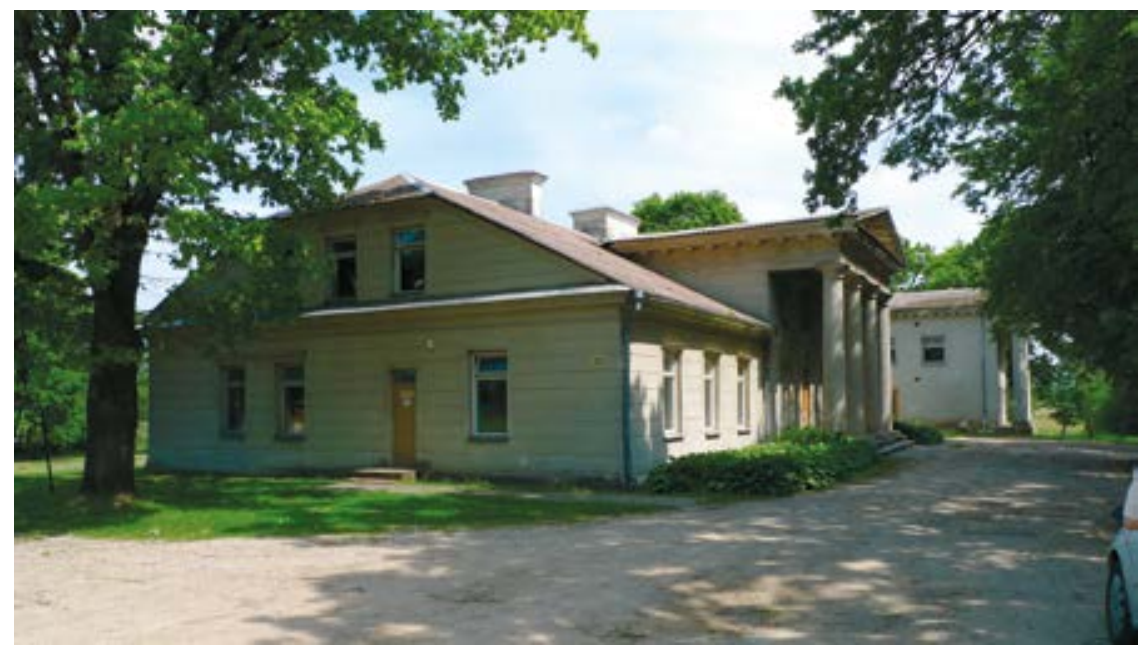

1.

Vakarinis ir pietinis rūmų fasadai. Tolumoje matyti pietinẻ buvusio grūdų sandèlio dalis, Dariaus Saltono nuotrauka, 2010
West and south façades of the manor in 2010 . The southern part of the former grain storage can be seen in the distance

Leipalingio dvaro rūmų kompleksą dabar sudaro trys tarpusavyje sujungti, XIX a. pradžioje - XX a. pradžioje statyti, ne kartą rekonstruoti pastatai - dvaro rūmai, oranžerija ir grūdų sandèlis. Sovietmečiu visi jie buvo labai grubiai pertvarkyti. Keliais etapais vykdytų architektūrinių tyrimų metu sužinota apie ansamblio statinių architektūros raidą, apie daugelio architektūrinių elementų formas iki pertvarkymų. Dvaro statinių vaizdus iki sovietmečio, XX a. pirmoje pusėje, primena Algirdo Volungevičiaus muziejuje Leipalingyje surinktos nuotraukos. Straipsnis skirtas atskleisti turimas žinias apie architektūros raidą, paviešinti duomenis, sudariusius galimybę restauruoti buvusią rūmų ir grūdų sandèlio architektūrą.

Sovietmečiu suformuoti ansamblio vaizdai [1, 2 il.] ir pastatų planai rodo XX a. antroje pusėje vykusių perplanavimų mastą, kardinalius XIX a. statinių projektų autorių sukurtos architektūros pakeitimus. Aiškių istorinių žinių, nurodančių rekonstrukcijų, ypač vykusių XIX a. ir XX a. pradžioje, datas ir pertvarkymų pobūdị, kol kas neturime. 2010 m. imtasi dvaro statinius tyrinėti ${ }^{1}$, ruošti jų tvarkybos ${ }^{2}$ ir pritaikymo XXI a. pradžioje susiformavusiems poreikiams projektus. Ankstyvujų pertvarkymų laikas ir jų

1 Darius Saltonas, Mokyklos pastato Alejjos g. 30 Leipalingio mstl., Druskininkų sav., pritaikymas bendruomenės centro veiklai. Istoriniai ir ikonografiniai tyrimai, 2010. Rengejjas UAB „Consena“ (at. Nr. 1965). Užsakovas Druskininkų savivaldybės administracija; Darius Saltonas, Glaudina Dobožinskaitè, Mokyklos pastato Alèjos g. 30 Leipalingio mstl., Druskininkų sav., 
pobūdis nustatytas daugiausia remiantis architektūrinių tyrimų išvadomis [3-5 il.]. XX a. antros pusės pertvarkymų laiką ir pobūdì padèjo patikslinti 1973 m. apmatavimų 3 ir 1980 m. tyrimų ${ }^{4}$ brèžiniai.

Pertvarkymų mastas, organizaciniai bei finansiniai nesklandumai pradejjus tyrimus ir projektavimą turejjo įtakos, kad žinių apie dvaro istorija ir architektūrą kaupimas nebuvo nuoseklus. Straipsnyje išdèstytos žinios neatspindi jų ieškojimų vingių. Dèl tų pačių priežasčių ypač svarbus šiame objekte buvo tyrimų rekonstrukcijos darbų metu etapas, tačiau ir jis nebuvo sklandus ${ }^{5}$. Kai kurios straipsnyje idètos tyrimų išvados preliminarios, tikslintinos atsiradus galimybei papildyti istorinius tyrimus.

Architektūros tyrimų tvarkybos darbų metu svarbą liudija daug pavyzdžių - tik išèmus sovietmečiu įstatytus langus pavyko nustatyti rūmų langų komponavimo langų angose kaitą Leipalingio dvaro rūmuose. Arba tik nuardžius iš silikatinių plytų suformuotus langų angokraščius atsidengė

pritaikymas bendruomenės centro veiklai. Architektūriniai tyrimai, 2010. Užsakovas Druskininkų savivaldybės administracija; Verutė Trečiokienė, Mokyklos pastato Alèjos g. 30 Leipalingio mstl., Druskininkų sav., pritaikymas bendruomenès centro veiklai. Pastato polichrominès analizės kūrinys tyrimai, 2010. Užsakovas Druskininkų savivaldybės administracija; Verutė Trečiokienė, Mokyklos pastato Alejos g. 30 Leipalingio mstl., Druskininkų sav., pritaikymas bendruomenės centro veiklai. Leipalingio dvaro rūmų vidaus patalpų papildomi polichromijos tyrimai - II, 2013. Užsakovas Druskininkų savivaldybės administracija, in: Druskininkų savivaldybės administracijos archyvas.

Evaldas Purlys, Mokyklos pastato Alejjos g. 30 Leipalingio mstl., Druskininkų sav., pritaikymas bendruomenès centro veiklai, $2010 \mathrm{~m}$. II etapo architektūriniai tyrimai. Užsakovas UAB „Consena“; Evaldas Purlys, Leipalingio dvaro sodyba (Atv 856), Dvaro rūmų vakarų (V) korpusas. Architektūriniai tyrimai tvarkybos darbų metu, 2014. Užsakovas UAB „Avona“, in: Druskininkų savivaldybès administracijos archyvas.

2 Mokyklos pastato Alejos g. 30 Leipalingio mstl., Druskininkų sav., pritaikymas bendruomenès centro veiklai, Kultūros paveldo objekto tvarkybos darbų projektas. Projekto vadovas Darius Saltonas, projekto dalies vadovas Evaldas Purlys, 2011. Užsakovas Druskininkų savivaldybès administracija, in: Druskininkų savivaldybès administracijos archyvas.

3 LTSR KŪM komunalinio ūkio projektavimo institutas, Druskininkų skyrius, Leipalingio vidurinės mokyklos II ir III korpusai. Apmatavimų brěžiniai. Kompl. / obj. Nr. 649/1, 1973, užsakovas Lazdijų rajono liaudies švietimo skyrius, in: Druskininkų savivaldybės administracijos archyvas; Leipalingio progimnazijos Algirdo Volungevičiaus kraštotyros muziejus.

4 LTSR KŪM komunalinio ūkio projektavimo institutas, Druskininkų skyrius, Leipalingio vidurinė mokykla. Tyrinėjimai. Obj. Nr. 69.25, 1980, užsakovas Lazdijų rajono liaudies švietimo skyrius, in: Druskininkų savivaldybės administracijos archyvas; Leipalingio progimnazijos Algirdo Volungevičiaus kraštotyros muziejus.

5 Darbai prasidejo $2012 \mathrm{~m}$. antrame pusmetyje, tačiau net iki $2013 \mathrm{~m}$. liepos pradžios nebuvo aišku, ar bus vykdomi architektūriniai tyrimai, ar bus vykdoma projekte numatyta priežiūra ir kas ją vykdys. Nepradejus bendradarbiavimo išardytos grindys, išvalytos pastogès, išimti sovietmety įstatyti langai. Nespèta iki galo ar bent detaliau išnagrinėti ir užfiksuoti svarbių pastato raidą ir net kai kuriuos architektūrinius elementus nusakančių detalių. Iš darbus Leipalingio dvaro rekonstrukcijos pradejjusios UAB „Kauno restauratorius“ (subranga?) 2014 m. objektą vèl perèmė UAB „Avona“. Po projekto korektūros atnaujinus darbus, tvarkybos darbų vykdymo priežiūrą perėmè kitas autorius, kuris pasitenkino iki šiol atliktais tyrimais. 


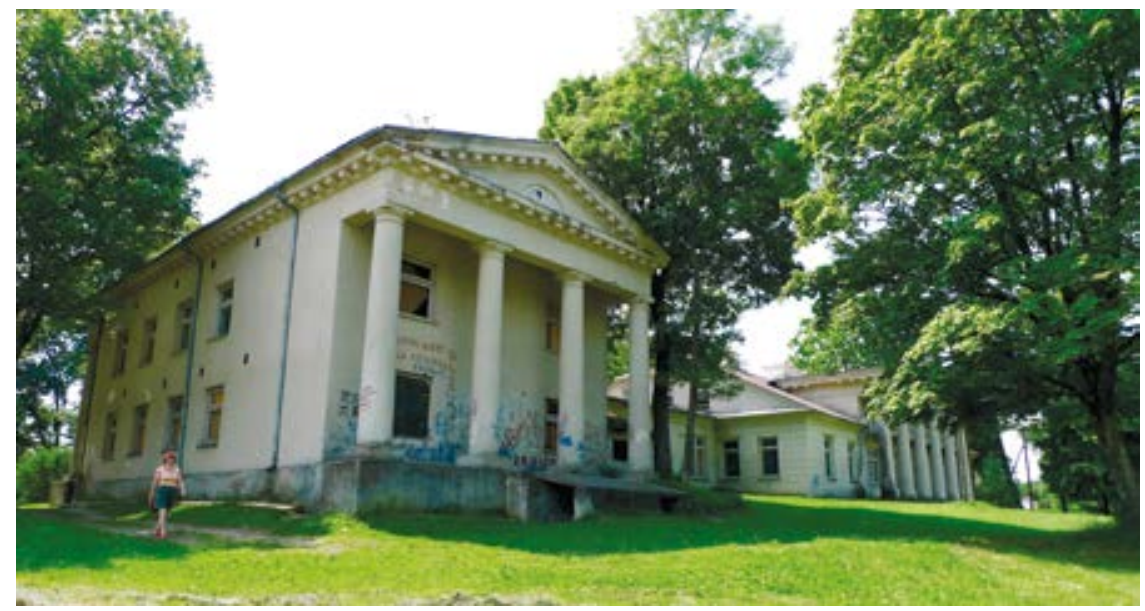

Rytinis ir šiaurinis buvusio grūdų sandèlio fasadai. Toliau matyti šiaurinè rūmų pusè, Dariaus Saltono nuotrauka, 2010
East and north façades of the former grain storage in 2010. The northern side of the manor can be seen further

pirmines grūdų sandèlio langų angų formas nusakantys angokraščių likučiai ar staktų pėdsakai. Sandèlio langų angos sovietmečiu buvo tiek padidintos, kad ieškoti pirminių langų angokraščių fragmentai atsidengè tik keliose vietose. Šiuokart ne natūros tyrimai patvirtino istoriniuose šaltiniuose užfiksuotas formas ar dydžius, o atvirkščiai - remiantis natūros duomenimis, jau nubraižius fasadų pirminio vaizdo retrospekcijas, netikètai sužinota apie ne per seniausiai i̇ muziejų patekusią nuotrauką su grūdų sandèlio vaizdu iki jo langų didinimo arba rūmų nuotrauką, kol rūmai dar nebuvo sujungti su grūdų sandèliu. Šie svarbūs ikonografiniai paliudijimai straipsnyje iliustruoja skirsnị apie grūdų sandèlio architektūrą.

\section{Istorinių žinių apie dvaro savininkus ir pagrindinius dvaro statybos etapus santrauka}

Pradejus restauruoti Leipalingio dvaro rūmus, išsamūs istoriniai tyrimai nebuvo atlikti. Vadinamuosius „Istorinius ikonografinius tyrimus“ 2010 m. pateikè projekto vadovas Darius Saltonas, kuris duomenis apie Leipalingị ir jo dvarą surinko iš Broniaus Kviklio enciklopedinio leidinio $M \bar{u} s u$ 


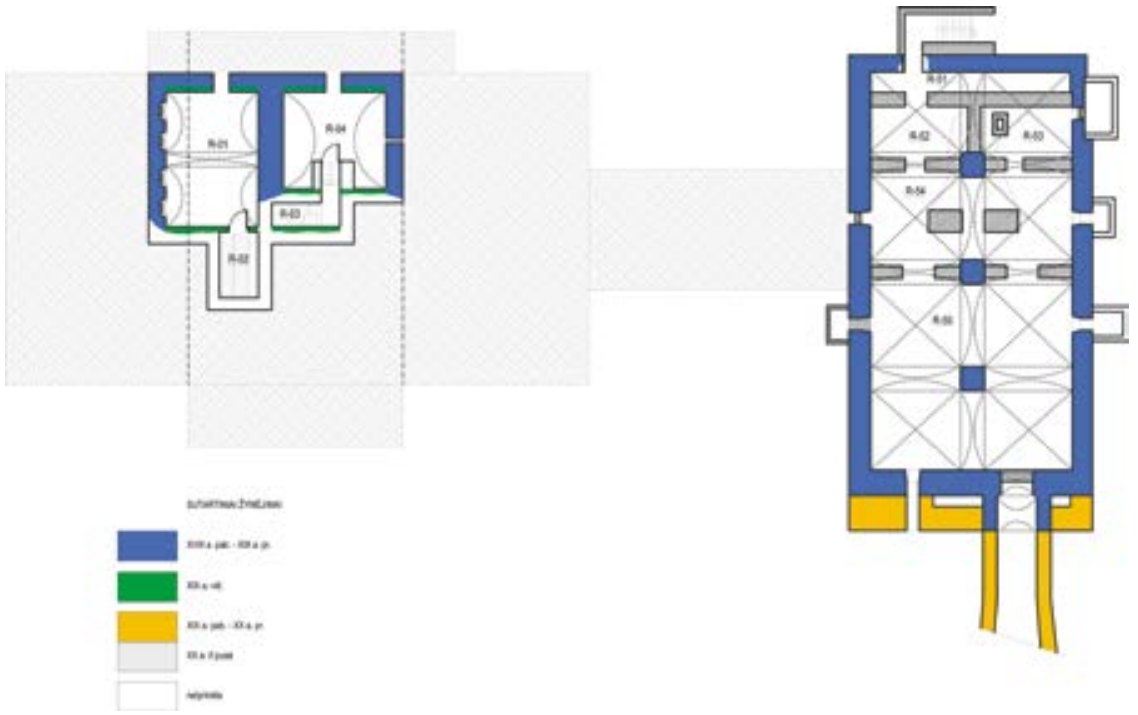

3.

Rūmų rūsio mūrų raidos kartograma, 2010, patikslinta 2020, sudarè Evaldas Purlys, braižè Darius Saltonas. Rūsių plane pažymètas pirmo aukšto centrinès dalies kontūras rodo, kad rūmų statybos metu siena buvusi maždaug dabartinio 110 kambario viduryje, ji mūryta ant skliauto
Cartogram of the development of the manor's basement walls compiled in 2010

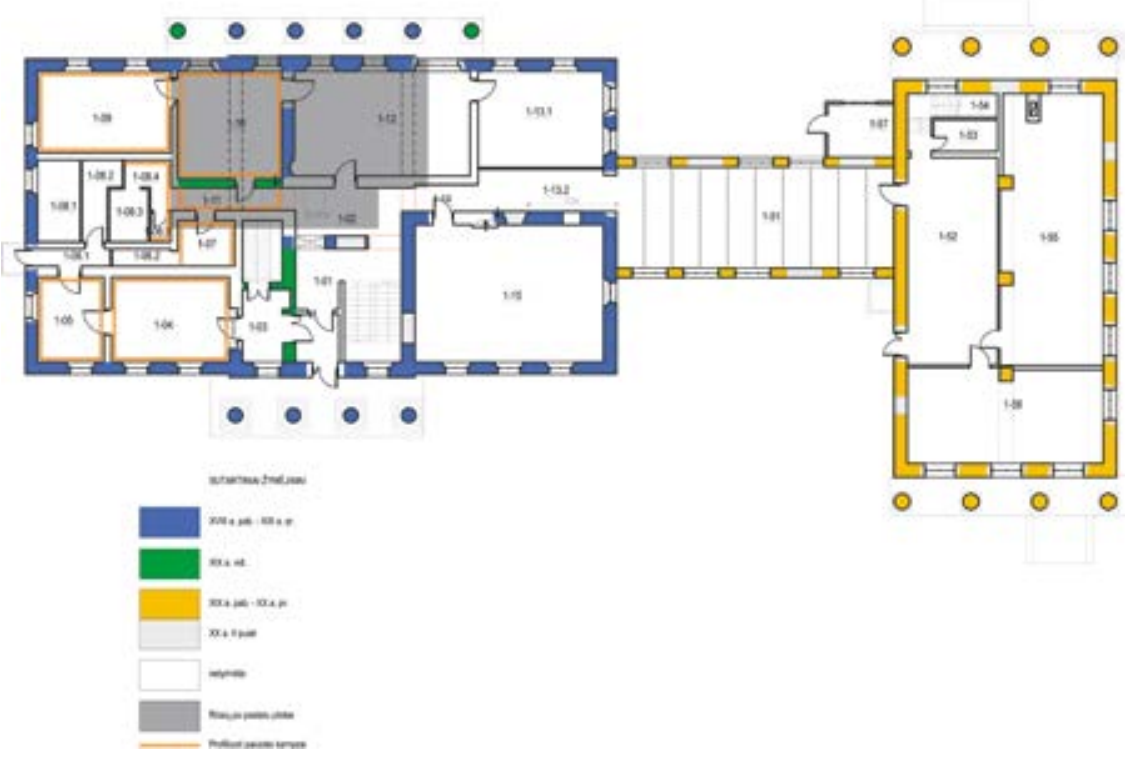

4.

Rūmų pirmo aukšto mūrų raidos kartograma, 2010, patikslinta 2020, sudare Evaldas Purlys, braižè Darius Saltonas
Cartogram of the development of the manor's groundfloor walls compiled in 2010 


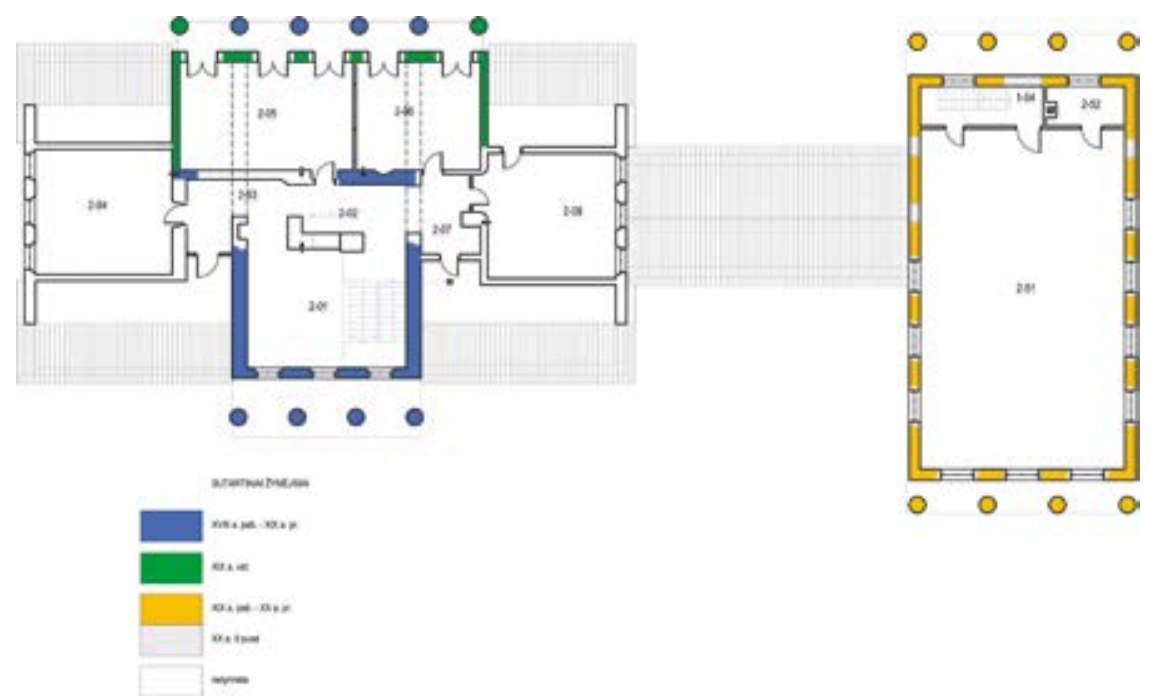

5.

Rūmų antro aukšto mūrų raidos kartograma, 2010, patikslinta 2020, sudarė Evaldas Purlys, braižè Darius Saltonas
Cartogram of the development of the manor's firstfloor walls compiled in 2010 
Lietuva $^{6}$ ir Ingridos Semaškaitès sudaryto žinyno Lietuvos dvarai ${ }^{7}$, taip pat pasinaudojo žiniomis, paskelbtomis internete. Rankraštinè medžiaga ir nuotraukos buvo gautos iš Algirdo Volungevičiaus muziejaus fondų Leipalingyje ${ }^{8}$. Nors tai tikrai nèra pakankami duomenys, jie neatskleidžia nieko nauja, kas buvo žinota anksčiau ${ }^{9}$, tačiau datos ir faktai surinkti i vieną vieta tampa aktualūs pagrindžiant kai kuriuos architektūrinių tyrimų rezultatus, todèl trumpai juos čia paminèsime:

Leipalingio dvarelis pirmą kartą paminètas $1503 \mathrm{~m}$. balandžio $7 \mathrm{~d}$., kai Leipalingis buvo atiduotas pabėgėliui iš Smolensko Jonui Pliuškovui iki to laiko, kol bus iš Maskvos išvaduota jo tėviškè.

1508 m. birželio 28 d. raštu Žygimantas Senasis padovanojo dvarą Juozui (Jonui) Sapiegai.

Nuo 1745 m. dvarą valdè Masalskiai.

Prieš 1792 m. dvarą nupirko Kruševskiai, nuo šio laiko ir XIX a. pradžios dvaras priklausė Kruševskių giminei. Apie 1800 m. dvaras su jam priklausančais kaimais ir miškais atiteko Vilniaus kapitulos pirmajam kanauninkui Antanui Kruševskiui.

XIX a. pradžioje klasicizmo stiliumi pastatyti dvaro rūmai. Architektas Martynas Knakfusas (1740-1821) ${ }^{10}$. Senoje sodybvietėje, kurioje nuo XVI a. stovėjo pastatai, èmė formuotis klasicistinė dvaro sodyba. Fundatoriumi laikomas Antanas Kruševskis, kartu pastatęs ir miestelio bažnyčią.

6 Mūsų Lietuva: krašto vietovių istoriniai, geografiniai, etnografiniai bruožai, paruošè Bronius Kviklys, Boston: Lietuvių enciklopedijos leidykla, t. III, 1966, p. 511-514.

7 Lietuvos dvarai: Dviejų tomų žinynas, t. 1, sud. Ingrida Semaškaitè, Vilnius: Algimantas, 2009, p. 11-12.

8 Darius Saltonas, Mokyklos pastato Alejjos g. 30 Leipalingio mstl., Druskininkų sav., pritaikymas bendruomenès centro veiklai. Istoriniai ir ikonografiniai tyrimai, 2010 .

9 Apie Leipalingio dvaro valdytojus ir statybos aplinkybes dar 1999 m. yra rašęs ir architektūros bei urbanistikos tyrinètojas Algimantas Miškinis knygoje Lietuvos urbanistikos paveldas ir jo vertybès. Užnemunès miestai ir miesteliai (Vilnius: Savastis, 1999, p. 327-374). 2015 m. straipsnyje „Dailès, paveldo moksliniai tyrimai ir jų reikšmè ịpaveldinimo procese“, remdamasi A. Miškiniu, Leipalingio dvaro istorinius duomenis trumpai pristatė paveldosaugos specialistė Margarita Janušonienė. Straipsnis publikuotas Vilniaus dailès akademijos rinkinyje Acta Academiae Artium Vilnensis (t. 77-78: Dailès ir architektūros paveldas: tyrimai, išsaugojimo problemos ir lūkesčiai, sud. Dalia Klajumienè, Vilnius: Vilniaus dailès akademijos leidykla, 2015, p. 297). M. Janušonienė taip pat pirmą kartą pristatė ir analizavo V. Trečiokienės tyrimų metu atrastą Leipalingio dvaro rūmų sienų tapybą.

10 Būtent A. Miškinis pirmasis iškèlè hipotezę, kad rūmus galèjo projektuoti garsus klasicizmo architektas Martynas Knakfusas. 1994 m. pasirodžiusiame Lietuvos architektūros istorijos antrajame tome aptariama Leipalingio dvaro rūmų klasicistinė architektūra, tačiau architektas nenurodytas; Lietuvos architektūros istorija: nuo XVII a. pradžios iki XIX a. vidurio, t. II, Vilnius: Mokslo ir enciklopedijų leidykla, 1994, p. 382-384. 
1820 m. Antanas Kruševskis dvarą paliko brolènui, Seinų apskrities bajorų maršalkai, seimelio nariui taip pat Antanui Kruševskiui.

1873 m. mirè Antanas Kruševskis. Varžytinèse dvarą nupirko Aleksandras O. Riurkė, Antano Kruševskio žentas. Paskui dvaras buvo atitekęs Kašicams, Kavaliauskui, iš kurio dvarą nupirko lenkas inžinierius Balinskis.

Balinskis planavo dvaro centre įrengti prašmatnią rezidenciją, apjuosti ją vandeningais kanalais iš čia pat esančio ežerèlio. Nemažai darbu buvo igyvendinęs, kanalus papuošęs įmantriais tilteliais, jungiančiais kanalų apjuostas pasivaikščiojimų ir piknikų saleles. Tarp rūmų ir grūdų saugyklos pastatė oranžeriją.

Artëjant Pirmajam pasauliniam karui dvaras parduotas Dernalovičiui, turèjusiam dvarų kažkur apie Minską. Dvarą tvarkè jo paskirtas žmogus.

Karo metu dvaras gerokai apniokotas. Valde ji vokiečių paskirtas žmogus.

Po Pirmojo pasaulinio karo Leipalingio dvaro savininkai liko Lenkijoje. Jų dvarą Lietuvos valdžia nacionalizavo ir 1923 m. vykdant žemès reformos įstatymus mažais sklypais išdalijo bežemiams ir kariams.

1923 m. dvaro rūmuose pradejjo veikti kun. A. Sivickio ir kalbininko S. Dabušio ịsteigta vidurinè mokykla.

1925 m. mokykla perėjo valstybės žinion, bet $1935 \mathrm{~m}$. perorganizavus Lietuvos mokymo sistemą buvo panaikinta.

1946 m. dvaro rūmuose vèl ėmė veikti mokykla.

$\mathrm{XX}$ a. antroje pusėje buvusio dvaro pastatai du kartus rekonstruoti.

Nuo 2010 m. prasidèjo Leipalingio dvaro natūros tyrimo ir restauravimo darbai, kurie su pertraukomis tęsiasi iki šiol. Būtent šių darbų duomenys ir pateikè svarbiausias žinias apie pastatu kaitą. $2010 \mathrm{~m}$. padaryti nedidelès apimties žvalgomieji visų ansamblio pastatų architektūriniai tyrimai ${ }^{11}$. UAB „Consena“ parengè projektą buvusio dvaro rūmų ansamblio pritaikymui Bendruomenės centro veiklai ${ }^{12}$. Grūdų sandèlio antrame aukšte numatyta

11 Evaldas Purlys, Mokyklos pastato Alejos g. 30 Leipalingio mstl., Druskininkų sav., pritaikymas bendruomenès centro veiklai, II etapo architektūriniai tyrimai, 2010.

12 Mokyklos pastato Alejos g. 30 Leipalingio mstl., Druskininkų sav., pritaikymas bendruomenès centro veiklai, Kultūros paveldo objekto tvarkybos darbų projektas. Projekto vadovas Darius Saltonas, projekto dalies vadovas Evaldas Purlys, 2011. Užsakovas Druskininkų savivaldybės administracija, in: Druskininkų savivaldybės administracijos archyvas. 
bendruomenės salè, pirmame aukšte - vestibiuliai, tualetai, keli darbo kambariai ir pan. Statytojas - Druskininkų savivaldybės administracija.

$2012 \mathrm{~m}$. antrame pusmetyje pradeti ansamblio gaivinimo darbai. Dvaro rūmai 2012 m. ir $2013 \mathrm{~m}$. buvo iš dalies restauruojami, pritaikomi Leipalingio bendruomenès centro veiklai. Vykdant tvarkybos darbus, buvo tęsiami architektūriniai tyrimai, tikslinamos priešprojektinių tyrimų metu užčiuoptų architektūrinių elementų formos, konstrukcijos ir pan. Po architektūrinių tyrimų 2010 m. išsakytos prognozès, kad dviejuose kambariuose gali būti likę polichrominio dekoro, pasitvirtino, be to, ant šių dviejų kambarių sienų 2012 m. rastas išlikęs kone visas polichrominis dekoras ${ }^{13}$. Druskininkų savivaldybėje dalyvaujant Restauravimo tarybai nutarta vieno kambario dekoro restauravimui skirti atskirą finansavimą, bet darbus atidèti iki bus aiškus finansavimo šaltinis. Dèl šios priežasties, taip pat atsiradus nenumatytų darbų projekte, nutarta $2011 \mathrm{~m}$. parengtą projektą koreguoti. 2014 m. balandžio mèn. parengta iki to laiko padarytų architektūrinių tyrimų ataskaita ${ }^{14}$.

$2014 \mathrm{~m}$. pateiktas ankstesnius sprendinius papildantis arba koreguojantis projektas ${ }^{15}$, tvarkybos darbų vykdymo priežiūrą ir naujų duomenų nagrinėjimą perėmė kitas autorius. Tęstinumo nutraukimas sutrukdè iki galo išsiaiškinti rūmų raidos niuansus ir labiau atsižvelgiant i anksčiau surastus elementus užbaigti tvarkybos darbus. Darbai rūmuose užbaigti 2014 m. pabaigoje, juose įsikūrè Leipalingio seniūnija, biblioteka, Leipalingio progimnazijos Algirdo Volungevičiaus kraštotyros muziejus ${ }^{16}$ ir kiti.

Po ilgokos pertraukos darbai Leipalingio dvaro ansamblyje atnaujinti tik 2019 metais. Pradèti buvusio grūdu sandèlio, vèliau mokyklos sporto salès rekonstrukcijos, dalinès restauracijos darbai. Atsirado galimybè

13 Verutė Trečiokienè, Mokyklos pastato Alèjos g. 30 Leipalingio mstl., Druskininkų sav., pritaikymas bendruomenės centro veiklai. Leipalingio dvaro rūmų vidaus patalpų papildomi polichromijos tyrimai - II, 2013, in: Verutès Trečiokienės asmeninis archyvas; Kauno paminklų restauravimo projektavimo instituto archyvas; Verutė Trečiokienė, Leipalingio dvaro rūmų vidaus patalpų papildomų polichrominių tyrimų programa, 2013, in: KPD Alytaus- Marijampolès teritorinio skyriaus archyvas. Šiame egzemplioriuje kartu su programa įdèta tyrimų ataskaita su planuose nurodytais zondais ir jų numeriais, stratigrafijos lentelèmis ir kt., trūksta kelių lapų.

14 Evaldas Purlys, Leipalingio dvaro sodyba (Atv 856), Dvaro rūmų vakarų (V) korpusas. Architektūriniai tyrimai tvarkybos darbų metu, 2014. Užsakovas UAB „Avona“, in: Druskininkų savivaldybės administracijos archyvas, Evaldo Purlio asmeninis archyvas.

15 Gražina Jarmalienè, Mokyklos pastato Alejjos g. 30 Leipalingio mstl., Druskininkų sav., pritaikymas bendruomenès centro veiklai, Leipalingio dvaro sodybos rūmai UK 15827, Techninio projekto korektūra - laida „B“, 2014, in: Druskininkų savivaldybės administracijos archyvas.

16 Muziejų 1957 m. ịsteigė mokytojas Algirdas Volungevičius (1923-2008). 
patikslinti grūdų sandèlio architektūros raidą ir jos vertingąsias savybes, kurios pasirodè gana netikètos. Naujame etape dirbama vadovaujantis dar 2010 m. parengtu techniniu projektu, kurio kai kuriuos sprendinius, darbuc metu atsiradus naujų duomenų, teko koreguoti. Buvusi grūdų sandèlį nuspręsta pertvarkyti ị salę su vestibiuliu, rūbine, darbo kabinetais ir pagalbinėmis patalpomis ịvairaus pobūdžio renginiams Leipalingyje.

\section{Leipalingio dvaro ansamblio pastatų raida, architektūros pokyčiai}

Nors ansamblio istoriniai tyrimai atlikti paviršutiniškai, tačiau pateikti duomenys parodè ilgą ir sudètingą dvaro raidą. Apie savininkų kaitą žinoma maždaug nuo 1500 m., yra fragmentiškų žinių apie Leipalingio dvaro žemes ir pan. Deja, kol kas mažai ką žinome apie kone 250 metų trukusi Sapiegų valdymo laikotarpi, nėra žinių, ką pastatè apie šimtą metų ji valdę Masalskiai bei po jų dvarą valdę savininkai. Iš muziejaus gauta $1685 \mathrm{~m}$. dvaro inventoriaus vertimo elektroninė kopija ${ }^{17}$ suteikè netikètai daug žiniu ne tik apie dvaro žemes, valstiečius ir jų gyvenamus kaimus, prievoles ir pan., bet ir apie Leipalingio dvaro sodybą, dvaro rūmus, jų planą, kai kurias architektūros detales. Dvaras tuomet priklausè Kazimierui Jonui Sapiegai. Klasicistinių dvaro rūmų suplanavimo struktūra, fasadų architektūra susiformavo per kelis statybu ir rekonstrukcijų etapus dvarą valdant Kruševskiams ir Balinskiams.

Iki restauracijos buvusi dvaro rūmų architektūra, nors ir gerokai deformuota, aiškiai išreiškė statybos laikotarpi - XVIII a. pabaigos - XIX a. pradžios klasicizmą. Leipalingio dvaro architektūra išsiskiria iš kitų vẻliau, net po šimtmečio statytų pagalbinès paskirties statinių derinimo prie senosios klasicistinès architektūros būdu.

17 Jono Reitelaičio istorinių dokumentų, liečiančių Leipalingị, vertimų su paaiškinimais bei komentarais byla. Elektroninès bylos kopijos saugomos Leipalingio kraštotyros muziejuje, Dariaus Saltono, Evaldo Purlio asmeniniuose archyvuose. Muziejuje yra popierinė elektrografiniu būdu padaryta kopija.

Byla susideda iš 288 ranka rašytų puslapių. Vienas ị lietuvių kalbą išverstų dokumentų 1685 m. sudarytas Leipalingio dvaro inventorius. Vertimo 205 puslapyje įdètos žinios apie Leipalingio miestą, 242 p. - dvaro rūmų aprašymas, paskutiniuose puslapiuose - dvaro rūmų planų schemos, Jono Reitelaičio sudarytos pagal $1685 \mathrm{~m}$. inventorių. 


\section{Dvaro rūmai}

Kur stovèjo senieji dvaro pastatai? Ilgą istoriją menančio Leipalingio dvaro sodyba apèmè didelị plotą, kuriame abipus dvaro rūmų buvo parkas, o netoliese ir dvaro ūkiniai pastatai. Leipalingis, kaip ir didelè dalis dvaro pastatų, pražuvo įnirtingų mūšių $1944 \mathrm{~m}$. liepą metu. Sovietmečiu dvaro sodybos pietinėje dalyje pastatyta vakarinė mokykla, buvusi sodų teritorija užstatyta gyvenamụjų namų kvartalu. Išliko rūmai su buvusiu grūdų sandèliu greta, dvaro sodybai priklausantys parko fragmentai ir miško parkas prie Seiros upès.

Kadangi dvaro rūmai buvo ne kartą perstatyti, todèl natūraliai kyla klausimas, kur buvo Leipalingio rezidencinio pastato pradinè vieta. Atsakymo, deja, neturime. Priešprojektinių tyrimų ir tvarkybos darbų metu aiškių ankstesnių laikotarpių mūrų pėdsakų rūmų sienose nerasta. Senieji statiniai galėjo būti nugriauti statant klasicistinius rūmus. Senụu mū murų liekanos ateityje dar gali atsidengti po rūmų grindimis arba archeologiniu kasinėjimų metu pasimatyti kur nors greta dabartinio pastato. Keliama hipotezè, kad vienas senujų pastatų galėjo stovèti virš skliautuotų grūdų sandèlio rūsių. Ikiklasicistiniam laikotarpiui gali būti priskirti ir du nedideli tarpusavyje nesujungti, su atskirais ịejimais rūsiai po dabartiniais rūmais. Tvirtų ịrodymų tokiai prielaidai pagrịsti neturime, nes labai panašios rūsio ir antžeminès pastato dalies mūrams naudotos medžiagos, o labiau išplèsti mūro atodangas arba padaryti archeologinių tyrimų nebuvo galimybès. Prielaidą, kad rūsiai (ar bent vienas jų) gali būti ankstesnio pastato reliktas, perša jų komponavimas po pastatu, nelabai patogūs iejejimai iš vestibiulio ir akivaizdūs pertvarkymų požymiai rūsio sienų mūruose. Nedidelè angelè (005) rūsio R-04 rytinėje sienoje rodytų, kad už jos gali būti kažkokia užpilta patalpa. Mintis, kad rūsiai ankstesni už pirmo aukšto mūrus, dar labiau sustiprèja pažymėjus rūmų centrinès dalies kontūrą ant rūsių plano [žr. 3 il.]. Abi rūsių laiptinès ne kartą pertvarkytos. Kad būtų aiškesnė dvaro rūmų vietos kaitos logika, pažvelkime ị dvaro sodybos ir rūmų kaitą ịvairiais istoriniais laikotarpiais.

Dvaro sodyba 1685 m. Leipalingị Sapiegos kelis kartus buvo ịkeitę ir vèl atpirkę, kelis kartus prieš įkeičiant rašyti inventoriai. Žinomas tik

Evaldas Purlys — Leipalingio dvaro pastatu raida: žvalgomuju architektūros tyrimu ir restauravimo duomenys 
vienas - $1685 \mathrm{~m}$. liepos $20 \mathrm{~d}$. sudarytas inventorius ${ }^{18}$. Dvaras tada îkeistas naudoti ponui Gedeonui Chaleckiui. Gal kur archyve guli dokumentai, galintys paaiškinti, kiek / ar šis įkeitimas yra susijęs su pasiruošimu pirkti žemes Vilniaus Antakalnyje 1689 m. Minètame 1685 m. inventoriuje išvardyti dvarui priklausantys kaimai su jų gyventojais, užfiksuotos gyventojų prievolès, pajamos ir t. t. Aprašyti tam pačiam savininkui priklausantys mažesni dvarai, gana smulkiai aprašyti dvaro sodybos pastatai, rūmai ${ }^{19}$.

Leipalingyje tuomet buvo bažnyčia, turgaus aikštė ir keturios gatvės su 108 sklypais prie gatvių - Merkinės, Gardino, Veisiejų. Viena gatvė pavadinta tiesiog gatve prie bažnyčios. Nurodytos net sklypų prie aikštės ir kiekvienos gatvès savininkų pavardès.

Mums labiausia rūpi dvaras, ypač jo rūmai, todèl pabandykime įsivaizduoti dvaro sodybą, kurioje, spėjama, stovėjo dviaukštis rūmų pastatas. $1685 \mathrm{~m}$. visi dvaro sodybos trobesiai buvo nauji ir sveiki. Nedidelio gaisro būta prie rūmų didžiujų vartų. Sudegę ar apdegę buvo vartai ir keli statiniai greta. Trys sodybos kiemai buvo aptverti medinėmis tvoromis. Aprašymas prasideda sudegusių vartų i kiemo, kuriame stovejjo vartų pastatas ir rūmai, aprašymu. Kairėje už vartų apdegusios arklidès, už jų, irgi kairėje - apdegusi troba, dar toliau vežiminè. Deja, dokumente taip ir nenurodyta, kurioje pusėje nuo vartų stovėjo rūmai, kuriose vartų pusėse buvo išdèstyti pastatai kituose kiemuose. İdedame panašios dvaro sodybos su trim kiemais, rekonstruotos remiantis $1592 \mathrm{~m}$. inventoriumi, pavyzdį ${ }^{20}$ [6 il.]. Skiriasi pastatų kiekiai abiejose sodybose, gerokai skiriasi tame ar kitame dvaro kieme išdèstytų pastatų paskirtys, kitokiomis tvoromis aptverti kiemai. Yra ir kitų skirtumų, tačiau matome, kad sodybos struktūra, pastatų dėstymas trijuose kiemuose išliko ir praėjus šimtmečiui.

$1685 \mathrm{~m}$. dvaro sodyboje iš rūmų einant vartų link buvo virtuvès namas, troba-maistinè su rūsiu. Rūmai su tame pačiame kieme stovinčiais pastatais buvo aptverti stačių lentų tvora. I palivarko, tvartų kiemą

18 Inventoriaus elektroninę kopiją atsiuntė Darius Saltonas, 2010 m. rinkęs istorines žinias apie Leipalingio dvarą. Rašant priešprojektinių istorinių tyrimų ataskaitą, šiuo dokumentu nebuvo naudotasi.

19 Jonas Reitelaitis, Leipalingio dvaro $1685 \mathrm{~m}$. inventoriaus vertimas ir paaiškinimai, in: Istorinių dokumentų apie Leipalingị vertimų byla, 242 p. Elektroninės bylos kopija yra Leipalingio kraštotyros muziejuje, Dariaus Saltono, Evaldo Purlio asmeniniuose archyvuose. Muziejuje yra popierinė elektrografiniu būdu padaryta kopija.

20 Neringa Dambrauskaitè, Lietuvos Didžiosios Kunigaikštystès bajom namai XVIXVII a. pirmoje pusèje, Vilnius: Vilniaus universiteto leidykla, 2019, p. 5, il. 5. 


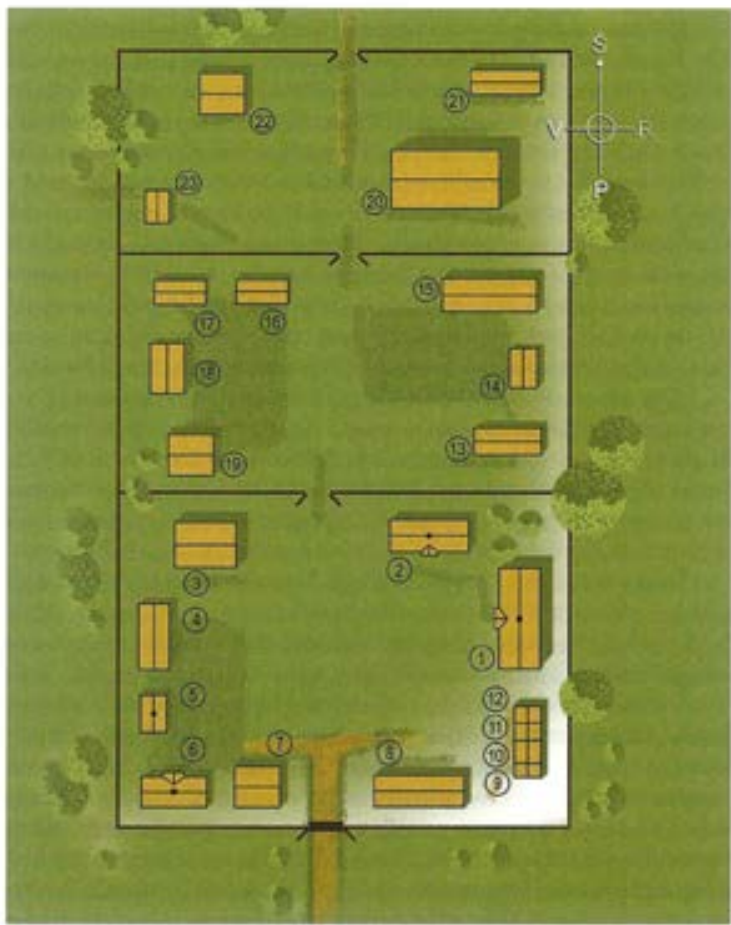

5 pay, $1592 \mathrm{~m}$. Vaitielaus Romanaviciaus Germaniskig̣ dvaro Minsko povicte trijy kiema sodyba, dail. N. Treinyx. Pagal $1992 \mathrm{~m}$, Germanikkiy dvaro invensoriy.

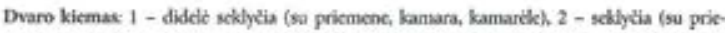

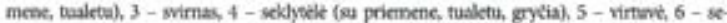

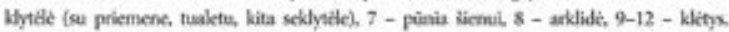
Dvardlo kiemas, 13 - Jeimynos grylia sa priemene, 14-18 - tvartai, 19 - pânia siaudams. Kluono kisemase 20 - kluonas, 21 - juja su priemene, 22 - púnia sienual 23 - pirtis su priemenc.
6.

XVI a. pab. dvaro sodybos su trim kiemais pavyzdys, in: Neringa Dambrauskaitè, Lietuvos Didžiosios Kunigaikštystès bajom namai XVI-XVII a. pirmoje pusëje, Vilnius: Vilniaus universiteto leidykla, 2019, p. 5, il. 5

Example of a manor with three courtyards of the late $16^{\text {th }}$ century

įvažiuojama per didelius vartus, kiemas aptvertas „štakietomis“, dešinėje du nauji dideli tvartai, nauja arklidè, taip pat trys mažesni tvartai. Iš tvartų kiemo vieni vartai vedè ị laukus, kiti - ị šeimynos (palivarko) kiemą.

Šeimynos troba dengta gontais, kažkur greta, nenurodant vietos, stovèjo ir kepykla. Iš palivarko kiemo einant per vartus rūmų kryptimi [atgal? - E. P.] tuoj už vartų - šulinys, kieme - nauja sūrinè. Tvoroje tarp palivarko ir kluonų buvo kiemų vartai. Kluonų kieme - didelis naujas kluonas su ketveriomis durimis ir keturiomis klètimis grūdams pilti. Čia pat ir antras didelis kluonas su trejomis durimis. Kažkur greta - didelė daržinė 
šienui krauti su dvejomis durimis, klètis su aruodais ant grindų, dar viena klètis su grindimis. Kurie pastatai kairèje, kurie dešinėje vartų pusėje, nenurodyta.

Iš kluonų kiemo einant bravoro link - vèl vartai. Bravore buvo pirtis iš tašytų sienojų. Panašu, kad bravoras stovejjo už tvoromis aptvertos sodybos ribų.

Dvaro rūmai 1685 m. inventoriuje. Pasak inventoriaus sudarytojo, rūmai buvo pastatyti ant aukšto mūrinio pagrindo, kuris buvo ne ant grūdų sandèlio rūsio, o kažkur kitur. Aukštas mūrinis rūmų pagrindas negalėjo išnykti be pėdsakų. Anksčiau ar vèliau jo žymės, o gal ir kontūrai bus išaiškinti, tik tam reikia archeologinių tyrimų programų ir jų finansavimo. Rūmų komponavimo ant grūdų sandèlio rūsių idèja atkrenta vien dèl to, kad inventoriuje išvis neminimi rūsiai arba kokie nors su rūsiais susiję rūmų plano požymiai. Dèl tos pačios priežasties ne 1685 m. rūmų reliktas ir rūsiai po dabar stovinčiais klasicistiniais dvaro rūmais. Bandant įsivaizduoti 1685 m. rūmus vis dar tenka remtis tik jo vaizdais tų metų inventoriuje.

Kaip liudija aprašymas dokumente, rūmai buvo vieno aukšto, mediniai, su patalpomis pastogèje. Stogas mansardinis, dengtas gontais. Virš stogo trys bokšteliai (kopulos (?)) buvo užbaigti žalvariniais rutuliais ir vejjarodèmis. Ant abiejų stogo galų - po žalvarinị bubą (?). İdedame preliminarias Jono Reitelaičio rūmų planų rekonstrukcijas, sudarytas remiantis aprašymu $1685 \mathrm{~m}$. inventoriuje. Panaudojus mastelyje nubraižytus ano meto rūmų langų dydžius ir jų dėstymo tvarką bei ritmą, truputị pakoregavus, papildžius gal pavyktų rekonstruoti rūmų planus šiek tiek tiksliau. Planai būtų gal aiškesni, tačiau vis tiek gerokai hipotetiški. Visiškai pagrịsstą, ịtikinamą rekonstrukciją, kaip ir kitais atvejais, kai pastato nebèra, o architektūriniais tyrimais negalima patikslinti jų plano, apsunkina kai kuriose vietose neaiškiai nurodytos vizitatoriaus èjimo kryptys, netikèti peršokimai aprašyme iš vieno pastato galo ị kitą, nutylëjimai ir pan. Tam, kad susidarytume rūmų plano vaizdą, J. Reitelaičio rekonstruotų plano schemų visiškai pakanka. Papildome jas svarbesnių kambarių aprašymais ir keliomis išvadomis apie galimus plano struktūros, silueto bei pjūvio niuansus.

$97-2020$

Acta Academiae Artium Vilnensis 


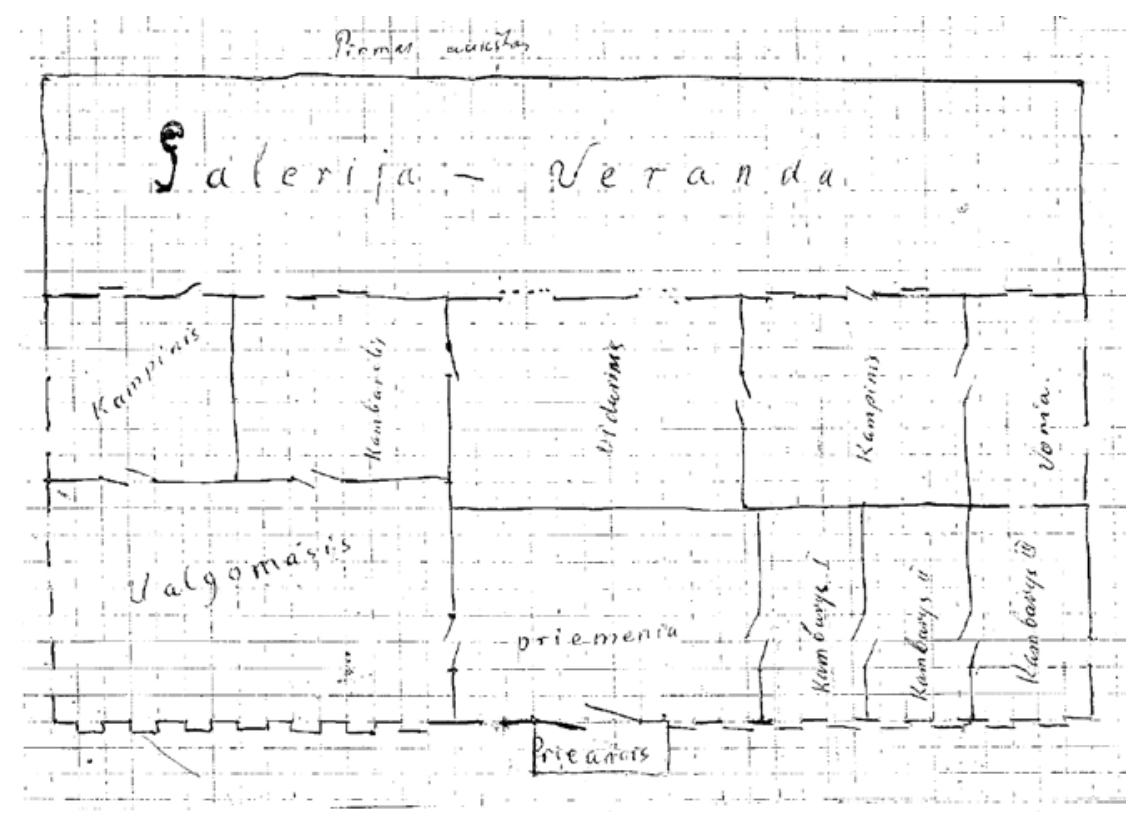

7.

Dvaro rūmų pirmo aukšto plano schema,

Drawing of the ground-floor plan of the manor

Jono Reitelaičio rekonstrukcija

Pirma patalpa iẹjus per priebutị i rūmus [7 il.] - didelè priemenė su trim dideliais langais ir dviem didelèmis krosnimis. Inventoriuje kažkodèl nepaminètos nè vieno kambario lubos. Aprašytos grindys, durys, suskaičiuoti langai. Grindys priemenėje iš plytų arba keraminių plytelių. Akivaizdžiai svarbus buvo kambarys priemenès dešinėje, nes durys i jị buvo ,juodu ąžuolu sagstytos (inkrustuotos?), su jų malonybių [Sapiegų, - E. P.] herbais“, su herbais buvo ir kambaryje stovėjusi baltų koklių krosnis. Grindys iš lentų. I kambarị už šio, pirmojo kambario durys daug kuklesnès, lygios, baltos, tačiau kambario grindys ,juodo ąžuolo su balto kvadratais“. Krosnis šiame kambaryje iš „,baltų glazūruotų koklių su židinèliu greta, langų įtvarai [staktos?, - E. P.] drožinèti“'21.

Rūmų kambariai buvo išdèstyti abipus pastato vidury pastatytos išilginès sienos. Atrodo, kambariai kitoje sienos pusėje buvo kuklesni, durys tarp jų lygios, grindys ir šiuose kambariuose lentų, kai kurios jų netgi 
pavadintos paprastomis. İdomiausias, bene daugiausiai klausimų užduodantis architektūrinis elementas prie šių kambarių - „galerija“. Taip ji vadinama inventoriuje. J. Reitelaitis ją vadina veranda. Kaip ją bevadintum, jos komponavimas prie pastato sudaro daug keblumų bandant rekonstruoti pastato vaizdą su galerija - tuo labiau kad virš jos buvo balkonas. Kaip veranda ir balkonas komponavosi prie mansardinio stogo? Inventoriuje mansardinis aukštas vadinamas antruoju aukštu. Galima būtų suabejoti mansardiniu stogu, tačiau vienas sakinys inventoriuje, tiksliau, vienas žodis, pavartotas aprašant antro aukšto salę ir patalpas greta salès, stogą tvirtai uždeda ne ant antro, o ant pirmo aukšto. Salè vienoje vietoje pavadinta tiesiog ,pastogine sale“"22.

Puošniausias ir svarbiausias kambarys pirmame aukšte - valgomasis su net vienuolika langų. İeinama i ji iš priemenès per duris kairèje priemenès sienoje:

Durys [i jị] dvivėrès, ąžuolinès, grindys lentų, krosnis didelè, įvairių spalvų, su herbais. Didysis dūmtraukis [virš židinio] su lipdyba, joje dviejų žmogučių atvaizdai. Iš valgomojo per paprastai padarytas dvivères duris patenkama ị kitą kampinị [kambarị prie galerijos]. Asla [kampiniame] iš plytų, du langai, dūmtraukis lipdytas [su lipdyba?]. Ir iš šio kambario durys ị galeriją. ${ }^{23}$

Vèl grižžtame ị priemenę, iš kurios buvo galima nueiti ir ị salę [8 il.]:

išèjus ị priemenę [iš valgomojo] iš dešinès mediniai laiptai su tekinto darbo turèklais ị [antrą] aukštą. [Antrame] aukšte salè. Salejje 12 langų, krosnis su nebaigtu dūmtraukiu, grindys pintai sudètos. Iš salès ị grotelėmis aptvertą balkoną išeinama per dvejas duris. ${ }^{24}$

Salè buvo ties priemene, abipus salès viršutinio aukšto galuose kambariai. Minima ir nedidelė priemenė su vienu langu. Viename kambarių buvo violetinès spalvos krosnis su dūmtraukiu, kitame, „kampiniame krosnis mūryta juostètai, su židinèliu“. Iš šių kambarių [kairiame pastoginès salès gale, $-E$. $P$.] išèjus, kitame pastoginès salès gale - laiptai žemyn ì 


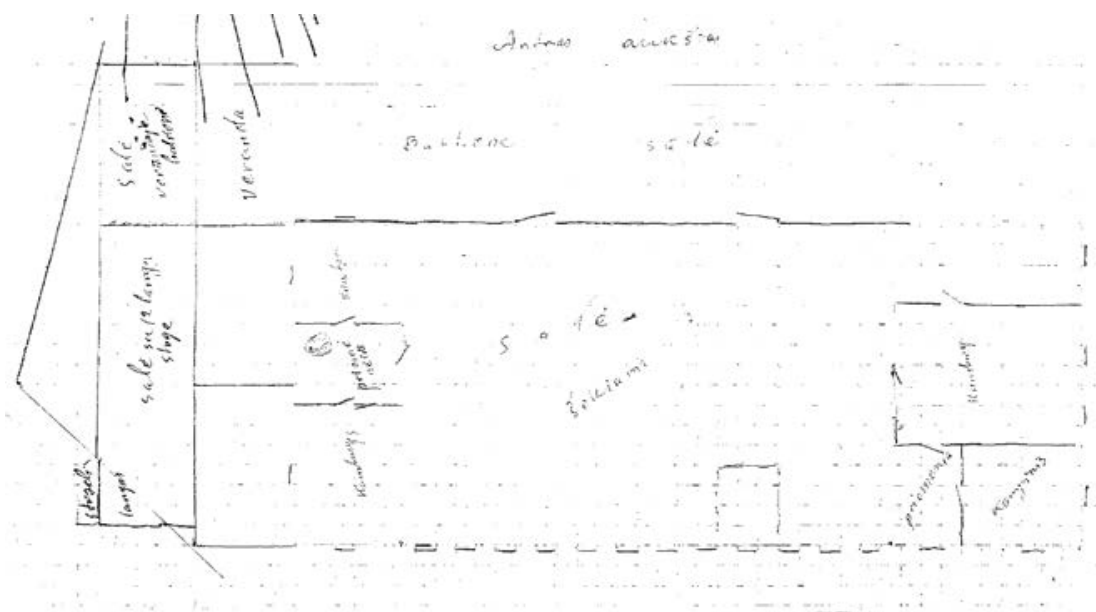

8.

Dvaro rūmų antro aukšto plano schema, $\quad$ Drawing of the first-floor plan of the manor Jono Reitelaičio rekonstrukcija

apatinę priemenę. Čia [salëje pastogèje, $-E$. P.] per dvivères duris dešinëje patenkama ị kambarị, o netrukus ir dar ị vieną kambarị dešiniajame salès gale. Iš aprašymų galima suprasti, kad rūmų galuose buvo po du kambarius, vienas iš kambarių kažkodèl pavadintas kampiniu. Sunkiau rasti vietą viršutinei priemenei, iš kurios „,per duris, suktais laiptais su turẻklais nusileidžia-

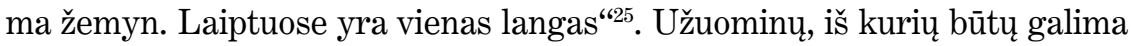
suprasti, ar šiame laiptų aprašyme patikslinama anksčiau paminètų laiptų i viršu forma, ar aprašomi antrieji laiptai i apačią, nèra. Visuose viršutinio aukšto kambariuose - po du langus.

Rūmų valgomajame ir kambariuose 40 didelių ir mažų stalų, 60 didesnių ar mažesnių kèdžių bei suolelių ir tik 5 lovos.

Inventoriaus pabaigoje aprašomos ir kelios, matyt, svarbios, charakteringos šiam pastatui ir jo išvaizdai fasadų puošybos detalès:

prie visu langu yra langinès. Langinès turi po 4 ịtraukas (filingus), jų viduriniai itvarai sudaro kryžių, [o kiekvienos jų, - E. P.] sankirtoje nutapytas Sapiegų herbas. Viduriniai įtvarai skirtinga spalva nei herbai nudažyti. İtraukos gėlètai nutapytos. [Antro] aukšto langai be langinių. ${ }^{26}$ 
Rūmai, sprendžiant iš langụ kiekio, vidurinès išilginės sienos pastato išilginėje ašyje bei kambarių kiekio tiek apatiniame aukšte, tiek viršutiniame aukšte, buvo ganètinai dideli. Kaip minejjome, stovejo jie ant aukšto mūrinio pamato, virš pastato buvo didelis barokinès formos stogas, kuris greičiausiai dengè ir galeriją. Dèl šios priežasties kambariai galerijos pusėje turèjo / galëjo būti siauresni nei kambariai priemenès pusėje, o pati galerija neplati. Kita šiandien žinoma žinia apie rūmus parašyta praėjus 67 metams. Paliko ją vokietis iš Gumbinès Vilhelmas Šlemyleris $1752 \mathrm{~m}$. (praèjus kone 10 metų po to, kai dvaras perèjo Masalskiams), važiuodamas per Leipalingị i Gardino seimą. Pavadino jis dvarą labai „dideliu, bet jau artèjančiu prie visiško sugriuvimo“. Atrodo, čia jis turejjo galvoje visos dvaro sodybos dydị ir jos būklę. Matyt, ir rūmus... Bažnyčia $1752 \mathrm{~m}$. buvo medinè.

Klasicistinių rūmų statyba. Iki mūsų dienų išlikę rūmai pastatyti XVIII a. pabaigoje - XIX a. pradžioje Lietuvos architektūroje įsigalint naujai madai - klasicizmui [9 il.]. Leipalingis tada priklausė Kruševskių giminei. Algimanto Miškinio nuomone, rūmus galëjęs projektuoti garsus klasicizmo architektas Martynas Knakfusas ${ }^{27}$, nors autorystės klausimas vis dar lieka atviras.

Dabartinio pastato išorè nėra iš esmès pakitusi, tačiau viduje jis yra vieną ar du kartus gerokai perplanuotas. Gaila, kad nepavyko rasti pirminio klasicistinių rūmų plano arba pirminę patalpų paskirtị aptariančio inventoriaus. Žinias apie tai ir prarastus architektūrinius elementus teko susirinkti tiriant išlikusius statinio mūrus [10, 11 il.].

Klasicistiniai rūmai buvo griežtai simetriškos architektūros, su keturių kolonų portikais prie pietinio ir šiaurinio fasadų. Siekiant labiau išryškinti portikus, fasadinių sienų plokštumos portikų zonose buvo iškeltos apie $15 \mathrm{~cm}$. Dabar šiauriniame fasade šešių kolonų portikas - šiauriniame fasade buvus keturių kolonų portiką rodo tokia pati fasadinès sienos iškiša kaip pietiniame fasade. Rūmų fasadai buvo tinkuoti lygiu, be rustiką imituojančio skaidymo tinku ir, atrodo, be sandrikų virš langų. Gerokai kitoks nei iki rekonstrukcijos buvo klasicistinių rūmų planas. 2012-2013 m. keičiant pirmo aukšto grindis buvo atidengtos kelių nugriautų rūmų sienų liekanos, kurios dabar, neturint istorinių senujų rūmų planų, padeda bent iš dalies rekonstruoti pirmụjų klasicistinių rūmų plano schemą. 


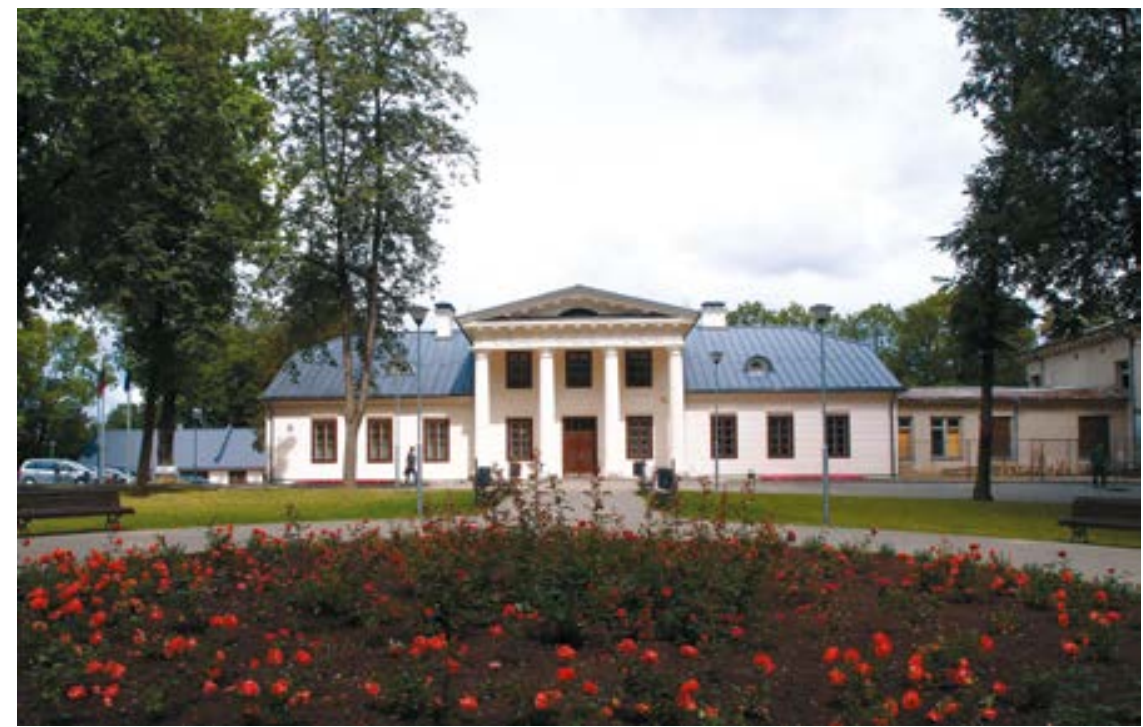

9.

Dvaro rūmų pietinio fasado vaizdas, Evaldo Purlio View of the south façade of the manor in 2019 nuotrauka, 2019

Statybos darbų metu, nuėmus grindis tarp 112 ir 118 kambarių, 4 ašyje atsidengè pirmas nugriautos kapitalinès sienos pamatas [12 il.]. Abiejose išilginėse kambario sienose (pamato galuose) rasti nuardytos sienos pėdsakai. Šios sienos šiauriniame gale, fasadinės sienos išorèje yra minètosios iškyšos šiaurès rytų kampas, o priekyje - kraštinè, ketvirtoji keturių kolonų portiko kolona. Nugriautoji siena statyta pirmajame rūmų raidos etape, nugriauta XX a. pirmoje pusèje, greičiausiai kuriantis mokyklai. Tokia pati, tik gerokai seniau nugriauta turèjo būti ir siena 2 ašyje. Siena orientuota link iškišos fasade ir pirmosios kolonos keturių kolonų portike. Ji nugriauta greičiausiai pirmosios rūmų rekonstrukcijos metu. Vien šios sienos nugriovimas ir kambario prie jos pertvarkymas rodo, kokio masto buvo ši rekonstrukcija.

Nugriautų sienų atkarpos pažymėtos pirmo aukšto plane su šiandienine rūmų plano struktūra ir patalpų numeracija. Kartu, siekiant palengvinti orientavimąsi architektūrinių elementų aprašymuose, plane palikta ir architektūrinių tyrimų metu naudota architektūrinių elementų numeracija.

Evaldas Purlys — Leipalingio dvaro pastatu raida: žvalgomuju architektūros tyrimu ir restauravimo duomenys 


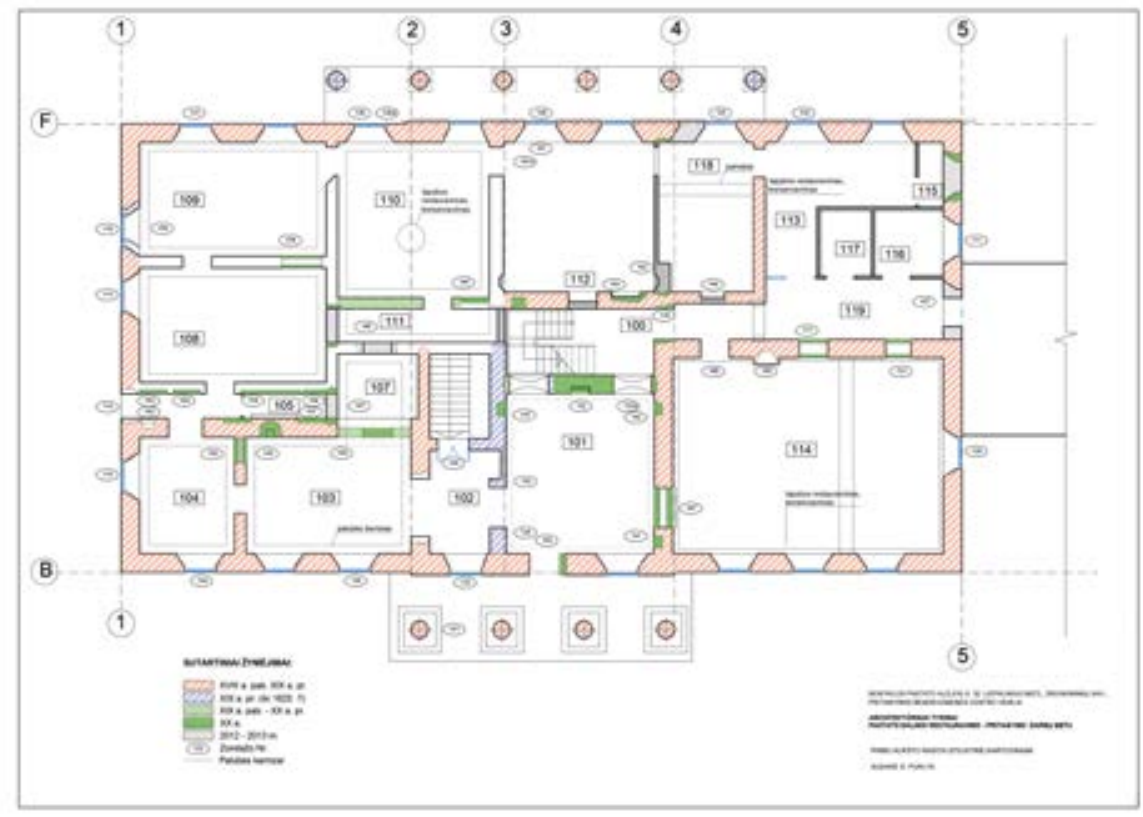

10.

Rūmų pirmo aukšto mūrų raidos kartograma, 2014,

Cartogram of the development of the manor's groundsudarè Evaldas Purlys

floor walls compiled in 2014

Senụjų rūmų vestibiulio prie pietinio portiko erdvẻ buvo platesnè, apėmè šiandieninio 101 vestibiulio ir greta vestibiulio 102 kambario erdves. İejimas ị ano meto vestibiulị buvo jo priekinès sienos centre, toje pat vietoje kaip ir dabar, o ị vakarinius (kairejje) kambarius - sienoje tarp 102 ir 103 kambarių. Dabar šioje vietoje pusapvalès formos anga.

Patalpa su priekinès sienos centre įkomponuotu pagrindiniu įejji$\mathrm{mu}$, atrodo, buvo ne tik platesnè, bet ir aukštesnè. Kitoje vestibiulio pusėje, prie vidurinès išilginès sienos (priešais pagrindinio įejjimo duris) buvo dveji laiptai, vedę ị du atskirus rūsius. Patalpų antrame aukšte tuomet greičiausiai buvo labai nedaug. Laiptai ị galimai mansardiniame aukšte buvusias patalpas galèjo būti už vidurinės išilginės sienos. Vestibiulyje nebuvo tambūro, užtat pagrindinio i̇ejjimo durys iškart buvo su kone $30 \mathrm{~cm}$ pločio stakta, komponuota fasado plokštumoje. Rasti to laikotarpio durų staktos atspaudai. Vidinėje plačios staktos pusèje galëjo būti antros, ị vidų atsiveriančios durys. 
Sprendžiant iš nugriautų sienų likučių išsidėstymo, dešinėje (rytinèje) rūmų pusėje prie šiaurinès sienos galėjo būti pagalbinės rūmų patalpos. Gal net ir virtuvè. Rytinėje rūmų pusėje, tarp 112 ir 113 kambarių buvo ịrengtas tamsus, atitvertas nuo lango 118 kambarèlis, o prie šiaurinès fasadinès sienos buvo $112 \mathrm{su} 113$ kambariu jungiantis 118a koridoriukas [žr. 10 il.].

Natūroje greta minètos sienos 4 ašyje buvo atkastas tamsuji kambarèlį nuo koridoriuko prie fasadinès skyrusios sienos pamatas. Išlikusioje pietinejje 118 kambarėlio sienoje rastas langas, skirtas produktams (?) paduoti ị dar mažesnę patalpėlę tarp 118 ir puošniojo 114 kambario [žr. 10 il.]. Abu tamsieji kambarèliai galimai skirti rūmuose vykusiems renginiams aptarnauti. Pagalbinių kambarių grupei anuomet galèjo būti skirtas ir kambarys šiaurès rytų rūmų kampe 1-13. Vèliau po rekonstrukcijos šis kambarys tapo vienu puošniausių rūmuose. Plačiau atidengti, nuvalyti, ištirti atkastų sienų fragmentų, deja, nebuvo galimybès, nebepavyko išsiaiškinti ir ar visos sienos mūrytos vienų statybų metu. Aprašytoji struktūra, atrodo, suformuota pirmajame klasicistinių rūmų statybos etape.

Nors keitèsi plano struktūra ir ne kartą buvo keičiami langai, jų angų vietos fasaduose, išskyrus vieną kitą ryškiau padidintą ar „pastumtą“ angą, nuo rūmų statybos meto nepakito. Pirminėse vietose tebėra pietinio (pagrindinio) ir šiaurinio fasadų langai, nedaug pakitęs jų dydis. Galiniuose rūmų fasaduose langai išdèstyti šiek tiek asimetriškai - vakariniame fasade buvo trys langai, rytiniame - taip pat trys, tačiau kiek kitaip komponuoti. Senujų rūmų langai, kaip jau minèta, buvo viengubi, atsiveriantys ì vidų, įstatyti pusės plytos gylyje nuo fasado paviršiaus, už užkarpų.

Užfiksuota įdomi rūmų šiaurinio fasado architektūrinė detalè [13 il.] - tokios pat nišutès po langu tik kiek blogiau išlikę fragmentai rasti ir po dar vienu langu. Iš atidengtų fragmentų galima suprasti, kad statant rūmus fasade po šoniniais langais už keturių kolonų portiko buvo suformuotos apie $5 \mathrm{~cm}$ gylio nišutès, kuriose buvo nupiešti grindis siekiančių langu rèmai. Langai tarsi siekè rūmų cokolį, žemès paviršių. Tarp langų, centre, už šiaurinio portiko, greičiausiai buvo durys kaip pietinėje pusejje. Tokių pačių nišučių pietiniame fasade nerasta arba neliko.

Evaldas Purlys — Leipalingio dvaro pastatu raida: 


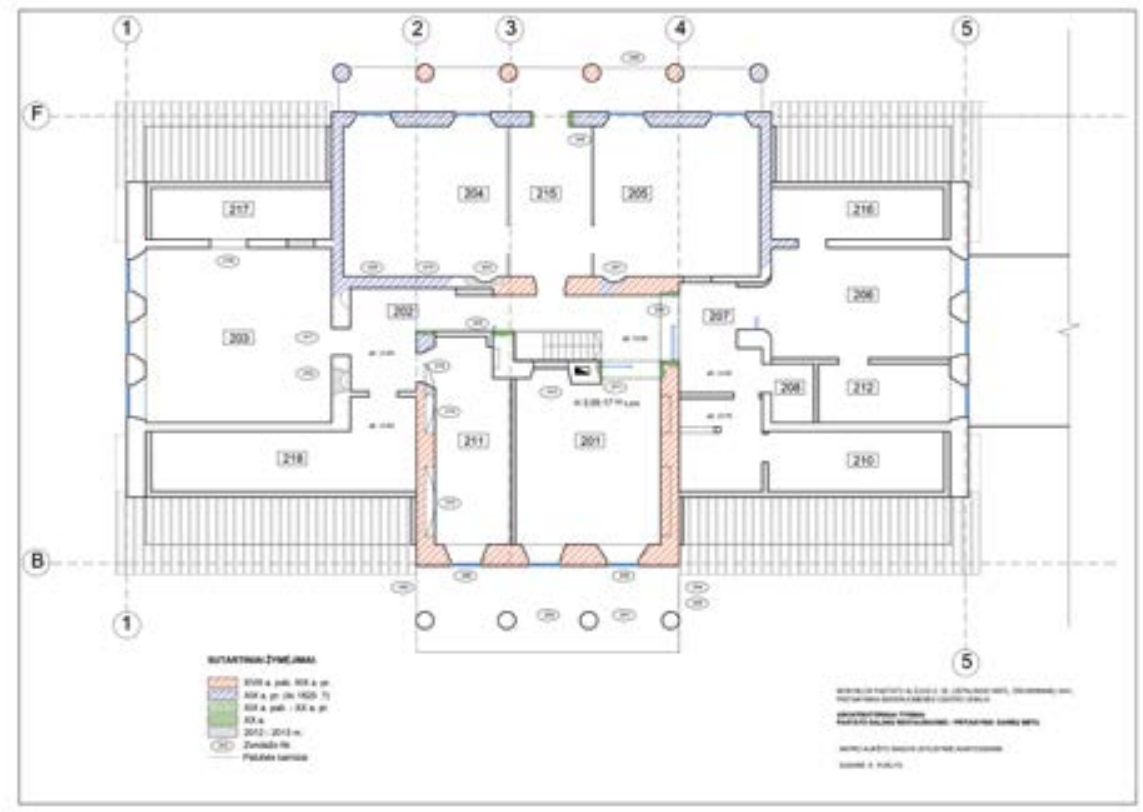

11.

Rūmų antro aukšto mūrų raidos kartograma, 2014, sudarè Evaldas Purlys

Cartogram of the development of the manor's firstfloor walls compiled in 2014

Būtinumą tyrinèti ir fiksuoti rekonstrukcijų metu atliktus pakeitimus iliustruoja vis nauja informacija - remontuojant pastatą keliose vietose pasimatè senoji tinkavimo maniera, sužinota apie sijas virš portikų kolonų ir jų apdailos konstrukcija. Perdangų konstrukcija medinè. Tinkuojant patalpų sienas ir lubas naudotos nendrès [14 il.]. Keliose vietose tinko ant nendrių ploteliai rasti ir išorėje, vėliau pertinkuotuose ploteliuose - atrodo, tokia tinkavimo technika šiame objekte naudota kone iki pat XX a. remontų. Iš man žinomų pavyzdžių seniausias pastatas, kuriame tinkuojant naudotos nendrès - Sapiegų rūmai Antakalnyje (1689-1692). Nors Leipalingio rūmai statyti tuo metu, kai horizontalioms tiesioms sąramoms virš angų jau naudotas metalas, Leipalingio rūmuose visos sijos virš portikų kolonų dar medinès. Ant atramų sudèta po tris aptašytus rąstus. Ruošiantis tinkuoti, sijų šonai ir apačia uždengta plokščiomis čerpèmis tvirtinant jas kalvio darbo vinimis plačiomis galvutèmis [15 il.]. Be to, dar 2010-aisiais tyrimų metu nustatyta, 


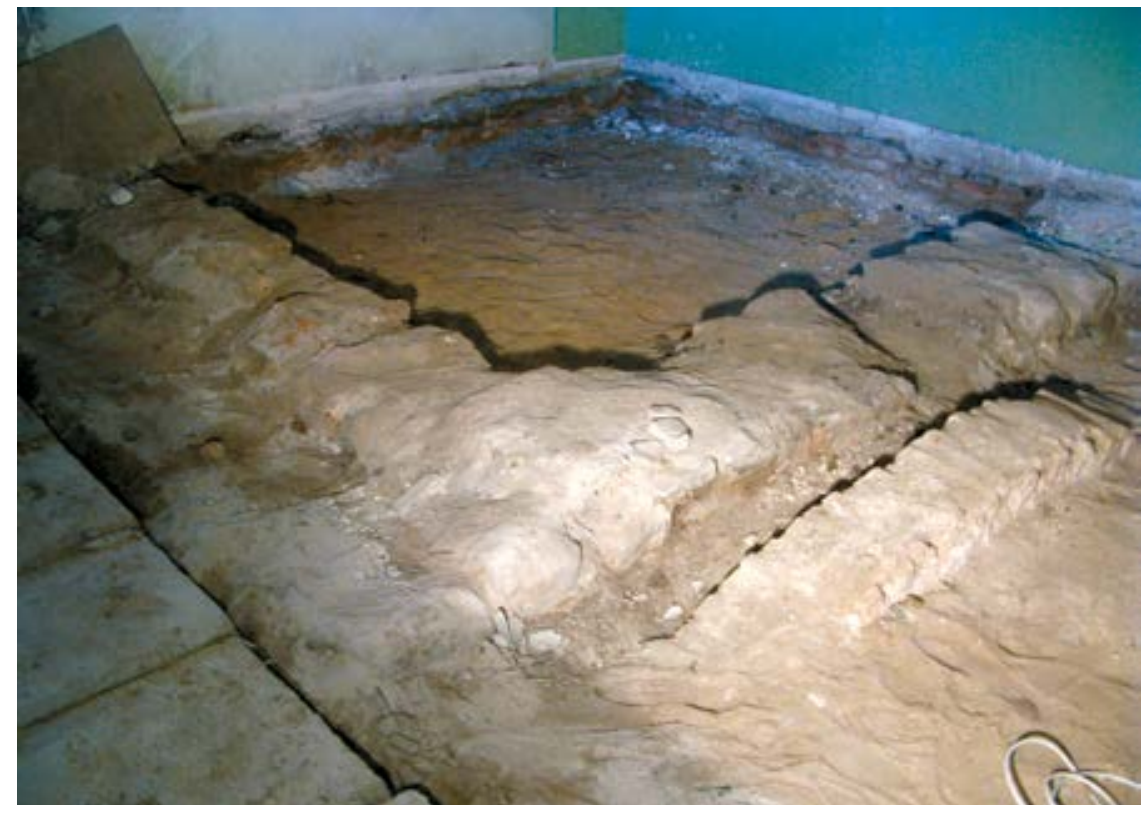

12.

Nugriautos sienos 4 ašyje pamato fragmentas (dešnejje) ir 1-18 koridoriuką nuo 1-18a patalpos skyrusios sienos pamatas (kaireje), Evaldo Purlio nuotrauka, 2011
Detail of the foundation of the demolished wall in axis 4 (on the right) and the foundation of the wall that separated corridor 1-18 from room 1-18a (on the left)

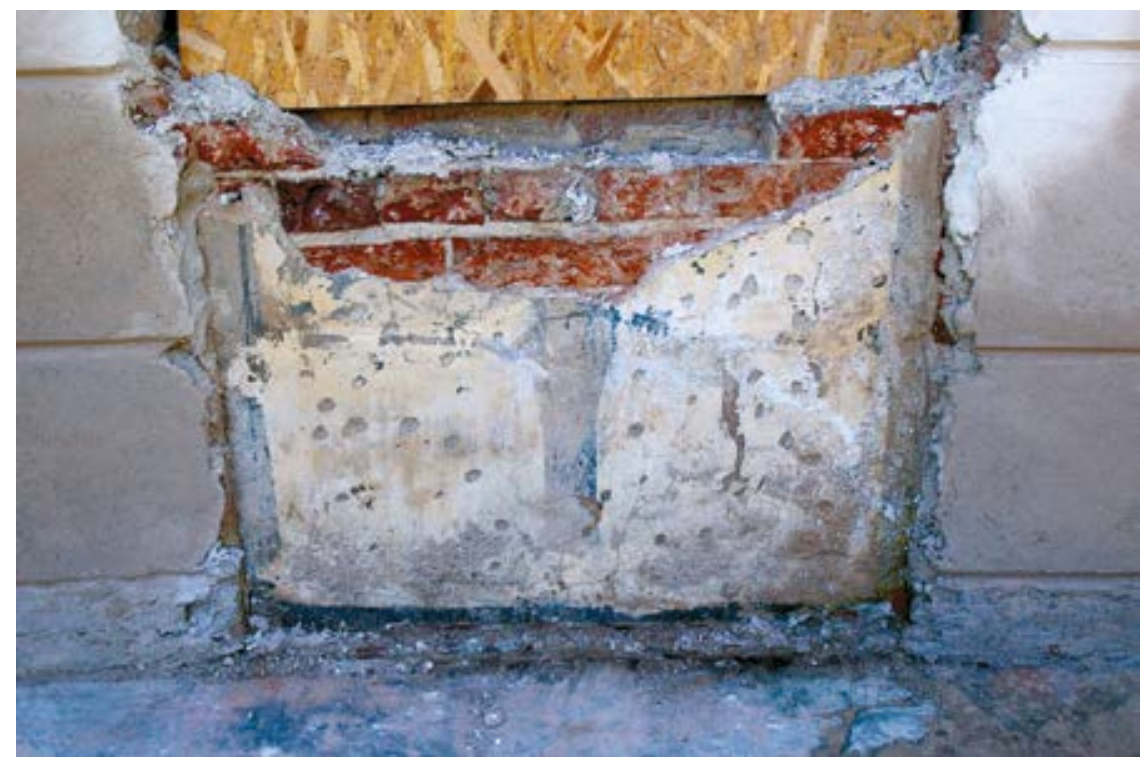

13.

Nišutè po langu šiauriniame fasade. Polichromija imituoja lango, siekiančio kiemo paviršiu, tęsinị, Evaldo Purlio nuotrauka, 2013
Small niche under the window on the north façade 
kad horizontalios juostos rūmų fasade nèra pirminès, jog jos tinke ịrěžtos gerokai vèliau, ir tik $2020 \mathrm{~m}$. pavyko išsiaiškinti, kad tai padaryta XX a. pradžioje, jau pastačius oranžeriją. Iki to laiko fasadų tinkas buvo lygus.

Pirmoji klasicistiniu rūmu rekonstrukcija. Pirmosios klasicistinių rūmų rekonstrukcijos vykdymo data nežinoma. $1820 \mathrm{~m}$. Antanas Kruševskis dvarą paliko brolėnui, Seinų apskrities bajorų maršalkai, seimelio nariui taip pat Antanui Kruševskiui. Istorinių žinių apie iki jo mirties $1873 \mathrm{~m}$. vykusias statybas neturime, o rekonstrukcijos metu padarytų darbu apimčių ir pakeitimų nustatymą komplikuoja rūmų statybos ir rekonstrukcijos metu panaudotų medžiagų panašumas. Natūros tyrimai rodo nemažus rūmų perplanavimo darbus. Kai kurie iš jų jau buvo paminèti rašant apie pradinị klasicistinių rūmų planą. Rekonstrukcija gali būti susijusi su savininko pasikeitimu, savininko poreikių padidejjimu. Ypač ryškiai pertvarkyta kairioji, vakarinè, rūmų pusè. Viena svarbesnių rekonstrukcijos užduočių gyvenamuju patalpų antrame aukšte įrengimas ar išplètimas. Atrodo, tuo metu ịrengtos ir patalpos pastogės galuose. Prireikė patogių laiptų i viršų.

Siekiant antrame aukšte ịrengti daugiau patalpu ir kartu mažiau pažeisti klasicistinę fasadų kompoziciją, šiaurinėje pusėje paplatintas portikas [16 il.]. Tos pačios rekonstrukcijos metu, bet greičiausiai kiek vèliau, po 1873 metŭ, jau šeimininkaujant dvare inž. Petrui Balinskiui (1861-1925), istoriko Mykolo Balinskio anūkui, tarp pastato ir šiaurinio portiko kolonu įrengtas metalinis balkonas. Iš pradžių manyta, kad šiaurinis portikas prie rūmų šiaurinio fasado perstatytas ar išplèstas grūdų sandèlio statybų etape, XIX a. pabaigoje - XX a. pradžioje, tačiau tokia išvada suabejota, kai nustatyta, kad grūdų sandèlio kolonoms ir portikams suformuoti naudotos geltonos, labai būdingos XIX a. pabaigai - XX a. pradžiai plytos. Naujos kraštinès šiaurinio portiko kolonos mūrytos iš raudonų plytų.

Sumanius išplèsti patalpas pastogėje, reikèjo sumažinti vestibiulio erdvę ir plotą. İejus į vestibiulį dabar atsiveria šiaurinèje jo sienoje suformuota kompozicija su dviem segmentinèmis arkomis perdengtomis angomis ir neplačia niša tarp jų [17 il.]. Už šių arkų ir sienos atkarpos su židiniu (?) tarp jų buvo laiptai ị antrą aukštą. İẻjimai ị rūmų kambarius - per simetriškai, viena priešais kitą sukomponuotas duris vestibiulio šoninèse sienose ir

$97-2020$

Acta Academiae Artium Vilnensis 


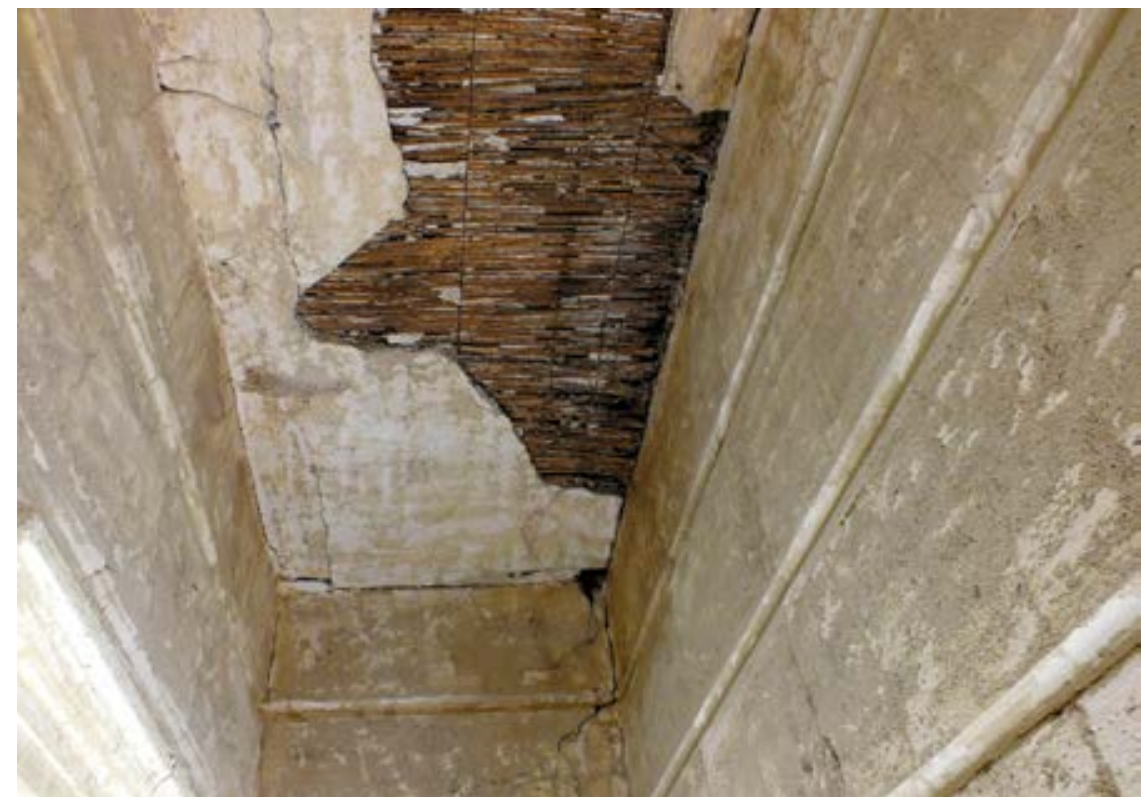

14.

Tinkas ant nendrių pietinio portiko lubose, Evaldo Purlio nuotrauka, 2013
Plaster on the reed in the ceiling of the south portico

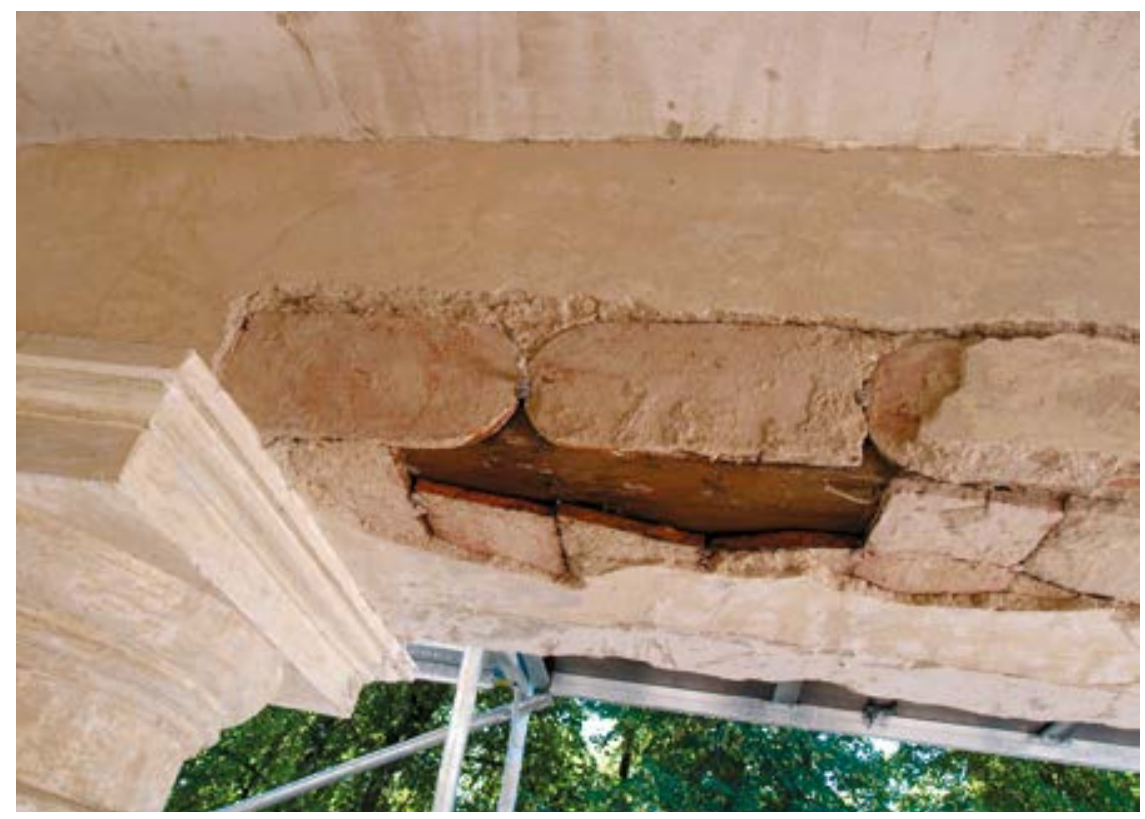

15.

Tinką laikanti konstrukcija ant pietinio portiko viršų laikančių medinių sijų, Evaldo Purlio nuotrauka, 2013
Construction protecting the plaster on the wooden beams supporting the top of the south portico 
po laipų maršu, sienoje už laiptinės. Virš abejų durų šoninėse sienose buvo kažkokie horizontalaus stačiakampio formos, epitafines lentas primenantys dekoro elementai. Viršuje kuklus palubès karnizas. Čia buvusi karnizą liudijo šiaurinėje sienoje išlikęs nedidelis karnizo mūro fragmentas. Ir po rekonstrukcijos vestibiulyje nebuvo tambūro, pagrindinio ịejjimo durys liko su labai plačia stakta, komponuota fasado plokštumoje. Ir dabar vidinėje staktos pusėje, kaip ir anksčiau, galèjo būti antrosios, ị vidų atsiveriančios durys.

Nuo vestibiulio kairėje pusėje atskirta 1-02 kambario erdvė. Naujoje sienoje suformuota durų anga. Išliko labai plačios durų staktos pèdsakai su nedideliu medienos gabalèliu. Atrodo, kartu siekta nuo vestibiulio atskirti ir vieną iš ịèjimų ị rūsius (antras ịèjimas ị rūsius gerai komponavosi po laiptais ị antrą aukštą). Nuo šiol ị pirmajị rūsị ịeinama laiptais iš atitverto kambario [18 il.]. Šis atrodytų nedidelis vestibiulio plano pakeitimas gerokai deformavo klasicistinių rūmų projekto autoriaus sumanytą centrinių erdvių ir jos architektūrinių elementų taisyklingumą, simetriškumą. Žiūrint iš vidaus pagrindinis ịejimas pasidarè nebe vestibiulio priekinès sienos centre. İejimas ị vestibiulị iš kiemo ịkomponuotas fasado simetrijos ašyje, tačiau asimetriškai vestibiulio vidaus erdvės atžvilgiu.

Tiriant vestibiulio sienose buvusius architektūrinius elementus, daugiausia pastangu ịdėti prireikè pirminių vestibiulio šiaurinès sienos architektūros elementų formų paieškoms. Čia sienos centre buvusios nišos vietoje daugelio remontų metu kirstos angos arba nišos, kuriose buvo statomos ir perstatomos krosnys. Neatpažistamai pakito ir šalia šoninių sienų buvusių angu su lanko formos sąramomis forma. Išlikę sąramų virš angu bei angokraščių fragmentai vis dèlto sudarè galimybę restauruoti visus šiaurinèje sienoje buvusius elementus [19, 20 il.]. Nesiryžta atkurti prie centrinės nišutės buvusio židinio priekinès dalies. Galimai čia buvusi židinị liudija sienoje, už nišutès sąramos ị viršų kylantis kanalas ir šioje vietoje ne kartą statytos bei perstatytos krosnys. Keli nenustatytos paskirties, panašūs ị krosnių pakuras elementai rasti abiejose šoninėse vestibiulio sienose, gaila, kad baigiamajame rekonstrukcijos etape jie nebuvo baigti tyrinèti. Liko nepažymėti šoninèse sienose virš durų buvusių stačiakampių plokščių su bareljefais (?) kontūrai.

$97-2020$

Acta Academiae Artium Vilnensis 
Laiptai i antrą aukštą buvo ịrengti toje pačioje vietoje kaip ir dabar - už vestibiulio šiaurinès sienos su arkomis, tik jie buvo kitaip suręsti. Natūroje rastos medinių laiptų konstrukcijos žymès. Nemažas laiptų pėdsako sienoje fragmentas rodo, kad kurị laiką po rekonstrukcijos, vykusios tarp 1820 m. ir 1873 m., laiptų pradžia buvo vestibiulio erdvèje prie dešiniosios (rytinès) vestibiulio sienos. Pakilus keliomis pakopomis, už aikštelès laiptai sukosi i kairę, kur tiesiu maršu pasiekè antro aukšto grindų lygị. Montuojant šio laikotarpio laiptus, dešiniosios angos dešinio angokraščio užkarpa (prie dešiniosios vestibiulio sienos) nutašyta. Gali būti, kad kažkur už šios sienutės buvo ir seniausias klasicistinių rūmų laiptų variantas. I vestibiulio zonoje likusius rūsio laiptus buvo einama per kairiają angą vestibiulio priekinëje sienoje. Durų angu galinėse laiptinės sienose tuomet nebuvo. Už sienos su dviem angomis buvę laiptai ị antrą aukštą ne kartą keitè konstrukciją, komponavimą. Žymiai panašesni ị senuosius mediniai laiptai buvo prieš sovietmečio pertvarkymus. Dar labiau nuo senujų skiriasi 20122014 m. rekonstrukcijos metu įrengti laiptai, kuriuos taip sukomponavus prarasta galimybė naudotis senaisiais laiptais ị rytinị (dešinị) rūsị. Kitokią šių laiptų architektūrą padiktavo naujos patalpų paskirtys, ypač naujiems tualetams parinkta vieta.

Sunku paaiškinti, kodèl statant klasicistinius rūmus dar buvo montuojami viengubi langai - tuo laikotarpiu net daugelyje senesniu pastatų langų angose, jei jų senieji langai dar būdavo geri, kone masiškai fasadų plokštumose arba arti jos jau buvo statomi antri, papildomi langai [21 il.], kurie galèdavo atsiverti tik ị išorę. Leipalingio dvare pertvarkant pastatą senieji langai buvo išimti, o nauji langai iškart pagaminti dvigubi ir įstatyti fasadų plokštumoje. Staktų plotis $20-24 \mathrm{~cm}$. Natūroje ant aptašytų užkarpų mūro rasta nemažai staktų, komponuotų fasado plokštumoje, atspaudų skiedinyje. Išorejje staktos ir mūro sandūros buvo uždengtos mediniais langų apvadais. Vidiniai, kiek ižăbūs angokraščiai liko nepakeisti. Panašu, kad to kažkodèl buvo ir siekta. Virš langų suformuoti sandrikai.

Didinant patalpas antrame aukšte sumanyta jas komponuoti už paplatinto dviem kolonomis portiko, abipus trijų sienoje už portiko buvusių langų suformuota dar po vieną langą [žr. 16 il.]. Antrame aukšte prie šiaurinio

Evaldas Purlys — Leipalingio dvaro pastatu raida: žvalgomuju architektūros tyrimu ir restauravimo duomenys 


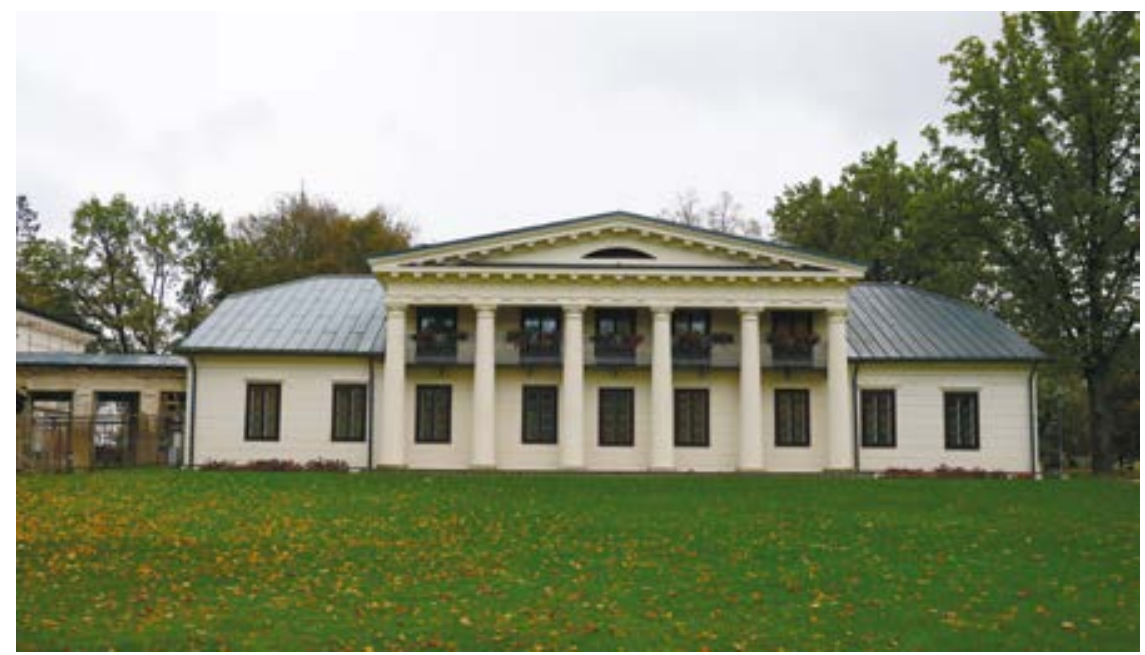

16.

Dvaro rūmų šiaurinis fasadas, Dariaus Saltono nuotrauka, 2020

North façade of the manor in 2020

portiko iš pradžių buvo ịrengta viena didelè patalpa su dviem pusapvalèmis nišomis krosnims patalpos pietinëje sienoje. Vèliau, greičiausiai po $1873 \mathrm{~m}$., išplèstos erdvès centre ịrengtas koridorius ị balkoną, o abipus koridoriaus po vieną didelị kambarị su apvaliomis krosnimis kiekviename. Deja, nebebuvo galimybės nustatyti, kada suformuota durų anga ị metalinị balkoną - ar didžiosios rekonstrukcijos metu, tarp 1820 m. ir 1873 m., ar po 1873 m. (inž. Balinskio (?)), ir kiek buvo duru i balkoną. Naujos sienos antrame aukšte medinės, karkasinès, ant lubų $2013 \mathrm{~m}$. dar buvo tinko plotų ant nendrių.

Pertvarkymu po 1873 m. požymiai. Jau minèta, kad bent dviejose rūmų patalpose, išmūrijus naują sieną, ant jos buvo padaryti lipdiniai kaip ant senụu sienų, o seni, i̇ atitvertą plotą patekę lipdiniai nenutašyti, išsaugoti. Taip pasielgta jau susiformavusiame, išpuoštame kambaryje, sumanius nuo jo atitverti koridoriuką ar padaryti kokią pagalbinę patalpą. Vieną pavyzdžių, iliustruojančių, kaip buvo elgiamasi koreguojant pastato planą, matome 110 kambaryje. Išlikę palubės karnizai rodo, kad pirminis rūmų 1-10 kambarys rytinèje rūmų pusėje (kairèje) po pirmosios rekonstrukcijos (?) buvo didesnis, apėmè ir 1-11 kambario erdvę. Tą patvirtina ant 


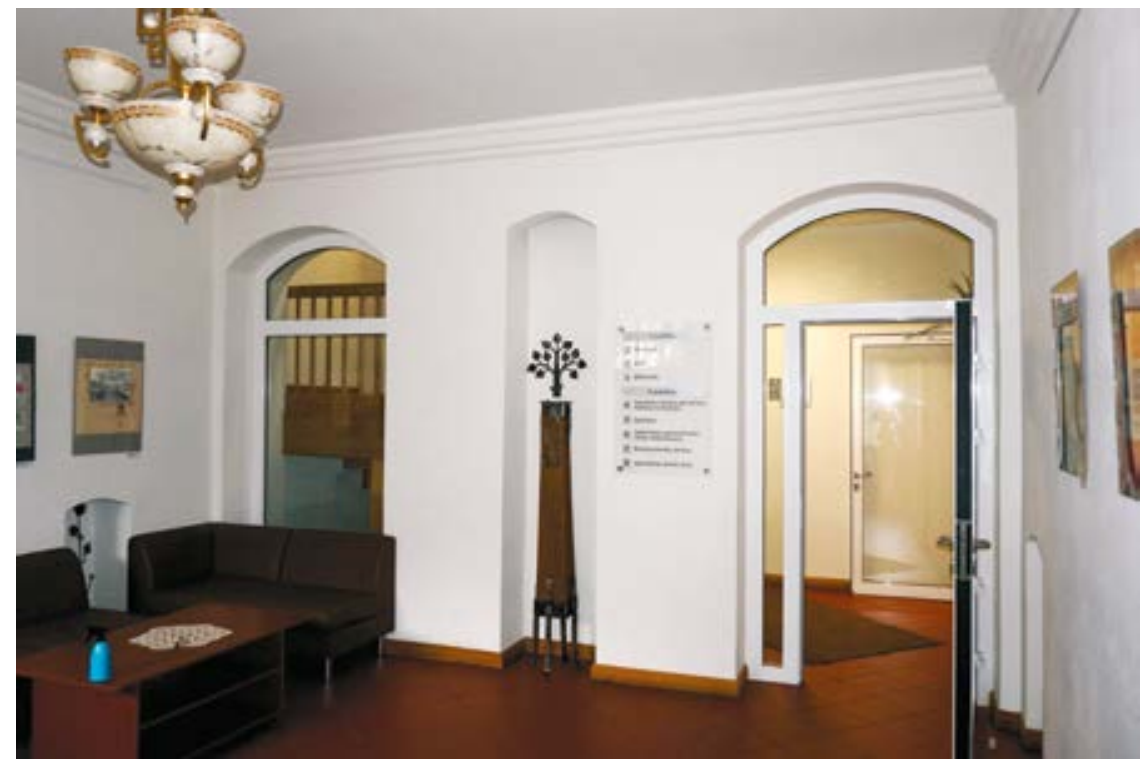

17.

Vestibiulio šiaurinė siena po 2012-2014 m. restauracijos, Dariaus Saltono nuotrauka, 2020

North wall of the lobby after the conservation of 2012-2014

mažesniojo 111 kambario vakarinès sienos likęs pirminis palubės karnizas ir didesniojo kambario lubų centre rasta rozete் ${ }^{28}$ [22 il.]. Kitoks pasirodè besąs ir pirminis 103 kambario kontūras - patalpa apėmè ir 1-07 kambarèlį. Sienos, skyrusios 1-03 ir 1-07 kambarius, nebuvo [23 il.]. Šiame ilgame puošniame L formos plano kambaryje šalia erdvaus vestibiulio galèjo būti svetainè arba valgomasis su nedidučiu apvaliu židiniu šiaurinėje sienoje [24 il.]. Didesnis, matyt, buvo ir 108 kambarys, nuo kurio atitvertas 105 koridoriukas dar vienam iejejimui ì rūmus. Koridoriukas su laiptine buvo sujungtas jau funkcionuojant mokyklai. Lipdiniai, senieji ir naujieji, pažymėti pirmo aukšto mūrų raidos kartogramoje.

Baigiant rekonstrukcijų metu padarytų pertvarkymų aprašymą, negalima nepaminèti dekoro. Daugeliu atvejų dekoras liudija ir kambarių plano pertvarkymus. Dar priešprojektinių tyrimu metu pastebėta, kad kambarių erdvės susiformavo per kelis raidos etapus ir jos neturi vieningo puošybos stiliaus, kad buvo keičiamos net palubès karnizais puoštos erdvès. 


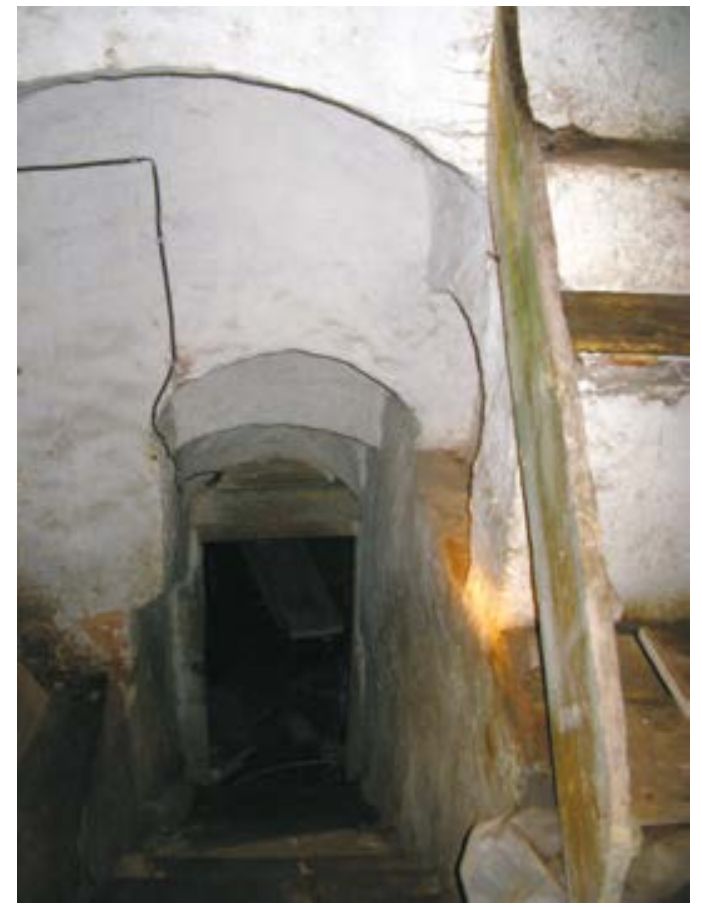

18.

Laiptai i vieną iš rūsių po rūmais, Evaldo Purlio nuotrauka, 2010

Stairs to one of the manor's basements in 2010

Vakarinio rūmų galo kambariai puošti gražiais profiliuotais palubès karnizais, kambariuose beveik nėra polichrominio dekoro. Šiuose kambariuose ar kai kuriuose iš jų sienos galèjo būti išklijuotos popieriniais sienų apmušalais. Ant langų ir durų angokraščių šiuose kambariuose kol kas rastas tik apvadus bei ịsprūdas (filingus) ant angokraščiu vaizduojantis polichrominis dekoras [25, 26 il.]. Kambariai rytiniame gale buvo be puošnių palubės karnizų, užtat gausiai papuošti polichrominiu dekoru ${ }^{29}$. Kokia yra to priežastis, kada tokios skirtingos dekoravimo sistemos sumanytos - projektuojant ar pertvarkant rūmus, vis dar nelabai aišku.

1-14 kambarys rytinėje (dešinėje) vestibiulio pusėje dabar didžiausias rūmuose. I jị ịeinama iš vestibiulio per plačias duris vestibiulio rytinėje sienoje. Tai puošniausias, gausiausiai polichrominiu dekoru puoštas

29 Verutė Trečiokienè, Leipalingio dvaro rūmų vidaus patalpų papildomų polichrominių tyrimų programa, 2013.

Kartu su programa įdèta tyrimų ataskaita (Verutė Trečiokienė, Mokyklos pastato Alèjos g. 30 Leipalingio mstl., Druskininkų sav., pritaikymas bendruomenès centro veiklai. Leipalingio dvaro rūmų vidaus patalpų papildomi polichromijos tyrimai - II, 2013) su planuose nurodytais zondais ir jų numeriais, stratigrafijos lentelemis ir kt. Trūksta kelių lapų.

Papildomų polichrominių tyrimų ataskaita saugoma ir tyrèjos V. Trečiokienès asmeniniame archyve. 
kambarys rūmuose. Per dvejas nedideles duris šiaurinėje kambario sienoje didysis 1-14 kambarys susisiekia su antru taip pat gausiai polichrominiu dekoru puoštu 1-13 kambariu. Natūroje po grindimis likęs pamatas rodo, kad pradinėje rūmų statybos stadijoje, iki kambario sienas padengiant polichrominiu dekoru, kambarị skaidè kapitali mūrinė siena. Durų angos liko iš pradinio klasicistinių rūmų statybos laikotarpio.

Šiaurinėje sienoje tarp dviejų durų angų tebèra pusapvalès formos plane židinys. Dabar židinys - ne sienos centre, nes taip buvo, kol nenugriauta minèta siena. Polichromuojant kambarị, gausiai dekoruota ir plokštuma virš židinio angos [27 il.]. Trečios durys toje pačioje kambario sienoje vedè ị pagalbines patalpas, irengtas dar statant rūmus.

Antrajame gausiai polichromija puoštame 1-13 kambaryje dekoras kuklesnis, mažiau jo ir išliko, tačiau viena, vakarinè, siena puošta išties ìspūdingai - sienos plokštumą jos centre skaide kelios meistriškai ištapytos kolonos su jonėninio orderio kapiteliais [28 il.]. Kompozicija su sienos centre pavaizduota anga ir sąramą virš angos laikančiomis kolonomis išliko. Už kolonų pavaizduota mėlyna dangaus žydrynė. Žemutinè sienos dalis apnykusi, nedaug ištirta, o kairioji pietinè sienos atkarpa, kurioje greičiausiai buvo durų anga, išgriauta. Gaila, baigiamajame rūmų tvarkymo etape planuotas eksponuoti plotas su kolonomis buvo sumažintas iki nedidelio plotelio su vieno kapitelio fragmentu, o šiame fragmente eksponuojamo kapitelio piešinys gerokai nukentėjęs, lyginant ji su buvusiu po atidengimo. Buvo galimybė eksponuoti ir gerai išlikusius apvadus aplink bent vieną 1-13 kambario langą, ir ant angokraščiu nupieštas ịsprūdas. Reljefinių palubės karnizụ abiejuose polichrominiu dekoru puoštuose kambariuose nèra. Nepavykus iškelti ị kitą vietą šiame kambaryje suprojektuotų sanitarinių ir techninių irenginių, atidengtas polichrominis dekoras 2012-2014 m. rekonstrukcijos metu uždengtas gipsokartono plokštèmis. Reikia tikètis, kad gal kada atsiras galimybe jị atidengti, restauruoti, eksponuoti. Polichrominis dekoras ant 1-13 ir 1-14 kambarių sienu priskirtinas XIX a. pabaigai - XX a. pradžiai ${ }^{30}$. Antro aukšto patalpose dekoro beveik nerasta.

Mokyklos ịkūrimas buvusiuose dvaro rūmuose. $1923 \mathrm{~m}$. dvaro rūmuose ėmė veikti kun. A. Sivickio ir kalbininko S. Dabušio ịsteigta vidurinė 


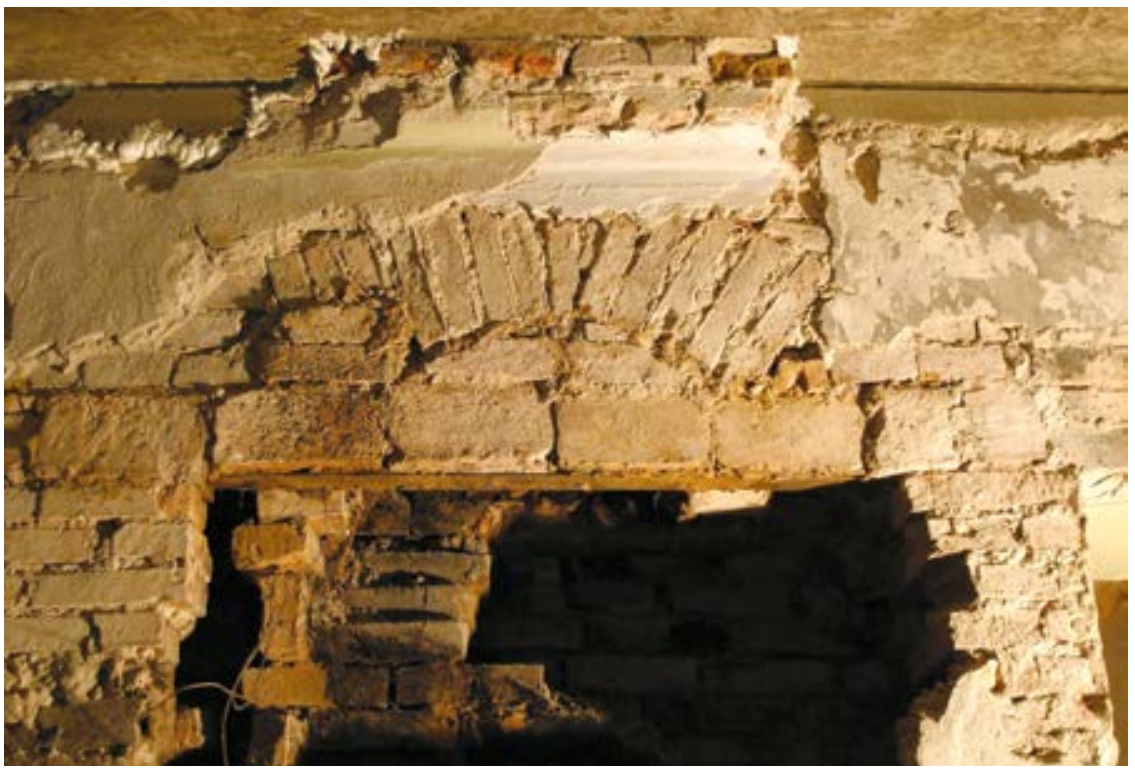

19.

Centrinės nišutės vestibiulio šiaurinejje sienoje vaizdas pradejjus restauraciją. Išliko sąrama, o apačioje prie grindų - šoninių ir dugno sienučių fragmentai. Virš sąramos likęs palubės karnizo fragmentas, Evaldo

Purlio nuotrauka, 2013
View of the central niche in the northern wall of the lobby after conservation

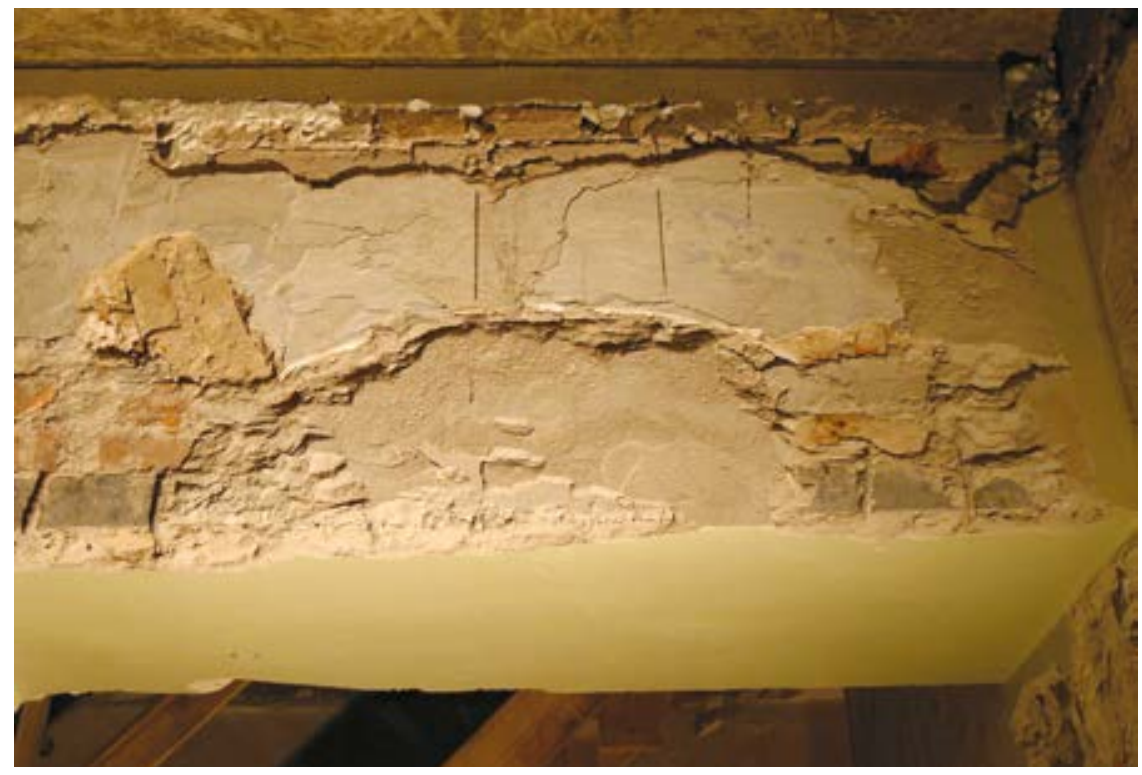

20.

Vestibiulio šiaurinėje sienoje virš dešinės angos lanko formos sąrama. Vaizdas pradèjus restauraciją, Evaldo Purlio nuotrauka, 2013
Arched lintel above the right opening in the northern wall of the lobby. View after conservation 


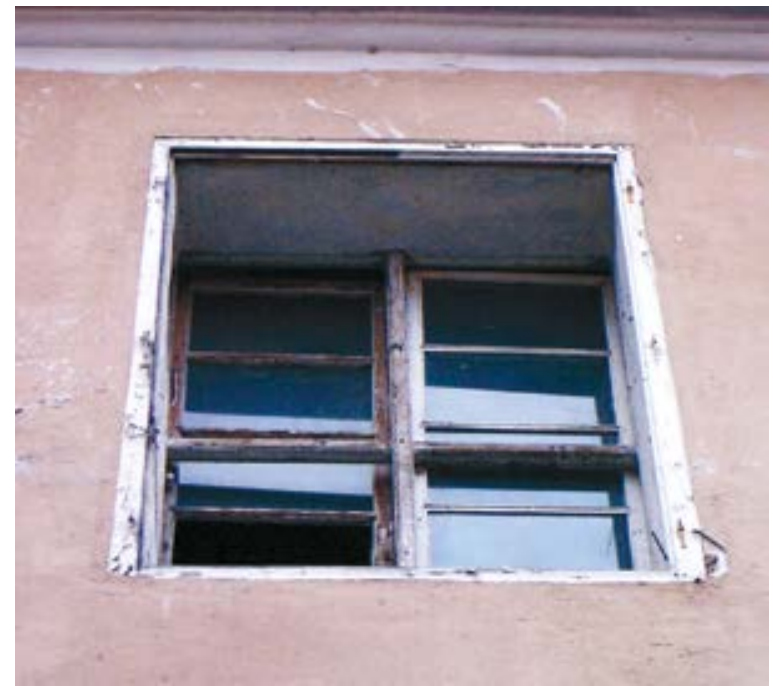

21

Dominikonų vienuolyno Vilniuje trečio aukšto langas fasade prie Šv. Ignoto gatvès. Fasado plokštumoje likusi klasicizmo likotarpiu sumontuoto lango stakta su trimis poromis vyrių, lango varčios - dvivėrès. Gilumoje matyti pirminè baroko laikotarpiu sumontuota lango stakta su keturiomis varčiomis, Evaldo

Purlio nuotrauka, 2004

Second-floor window of the

Dominican monastery on

Šv. Ignoto Street in Vilnius

mokykla, 1925 m. ji perėjo valstybės žinion. Dvaro rūmų pritaikymas mokyklai pareikalavo nemažai pastato pertvarkymų. Matyt, prireikus daugiau klasių, buvo išgriauta siena tarp 112 ir 118 kambarių. Ilgainiui iškirstos kelios naujos duru angos. Tarpukario remontui priskirtini iki 1987-1989 m. rekonstrukcijos buvę mediniai laiptai ị antrą aukštą.

Mokyklos pastato plano keitimai XX a. antroje pusèje. Butas mokytojui šiame pastate ịrengtas netrukus po karo. Didžiausi pakeitimai rūmuose susiję su bandymais pertvarkyti rūmų amfiladinę sistemą ị koridorinę. Kelios senos durų angos užmūrytos, kelios šiek tiek performuotos. Iškirsta ir naujų durų angų. Pastatą pamažu siekta kiek galima geriau pritaikyti mokyklai, tačiau 1980 m. konstatuota, kad:

pastatas visiškai nepritaikytas švietimo ịstaigai. Nèra rekreacijos, pasiskirstymo koridoriaus, klasès pereinamos, koridoriai siauri ir tamsūs. < ...> laiptai ị II aukštą mediniai, siauri. Laiptinė tamsi. Laiptai labai nepatogūs. Ypač mokiniams. < ...> Langai siauri, su smulkiu rèmų dalijimu. ${ }^{31}$

1980 m. atlikti tyrinėjimai, ruošiantis naujam mokyklos plano ir architektūros „pagerinimo“ etapui. Nežinia kodèl, tačiau projektus 


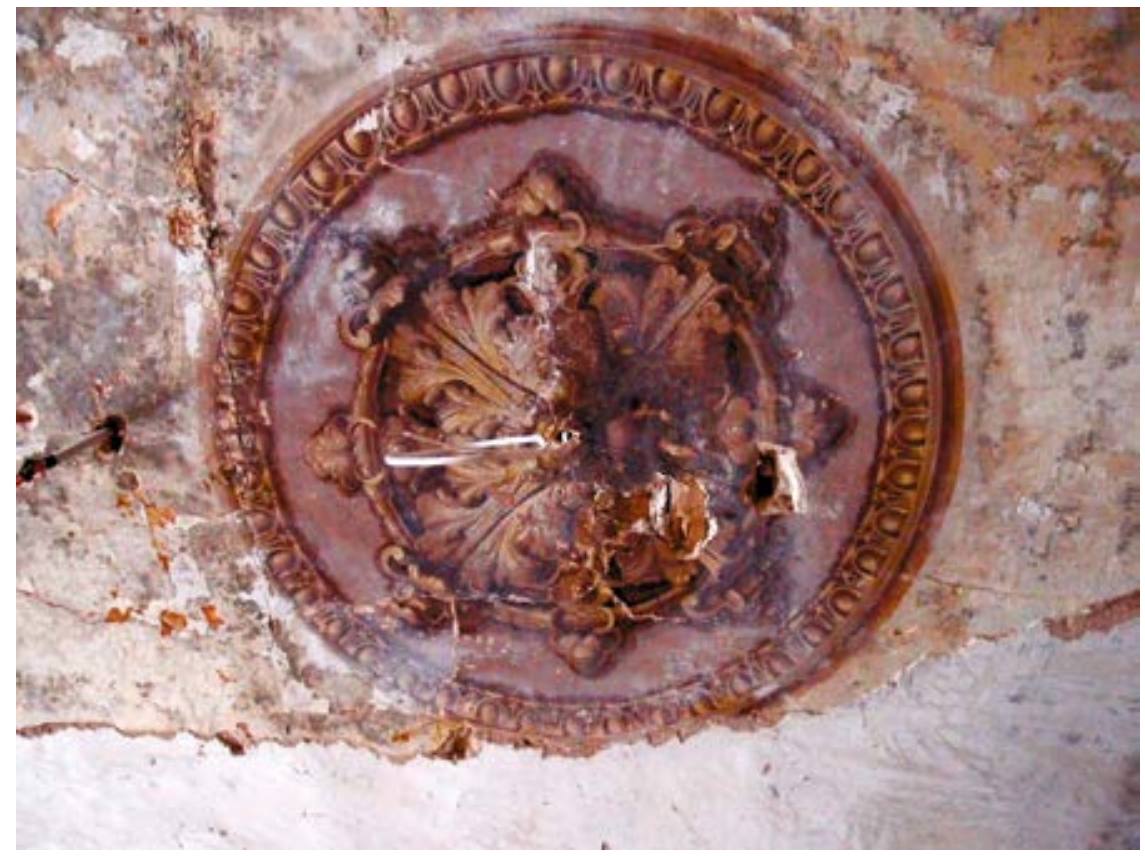

22.

Tapyta rozetė 1-10 kambario lubų centre. Baigiamujų tvarkybos darbų metu ji buvo uždengta gipso kartono plokšte, Evaldo Purlio nuotrauka, 2014
Painted rosette in the centre of the ceiling of room $1-10$. In the final stage of reconstruction, it was covered with a gypsum plasterboard

prižiūrinčios ir derinančios valstybinès institucijos leido gerokai pakeisti ne tik vidaus planą, bet ir fasadų architektūros charakterị - sovietmečio rekonstrukcijų metu pakeisti rūmų langai ir jų skaidymas, šiek tiek padidintos jų angos, iškirsta 112 lango anga ir kt. Elgtasi lyg rūmų ansamblis nebūtų klasicistinis Lietuvos kultūros paveldo objektas, lyg Lietuvoje nebūtų buvę paveldosaugos institucijų ir jos valdininku.

1987-1989 m. dar kartą tobulinant koridorinę sistemą laiptai perkelti ị vestibiulį. Iškẻlus laiptus ir antrame aukšte susiformavo daugmaž aiški koridorinè sistema. İ istorinę rūmų planavimo sistemą ar langų skaidymo sistemą nebuvo kreipiama dèmesio. Langai parinkti iš to meto tipiniu langu katalogo. Antrame aukšte ir vestibiulyje iš dalies pakeistos perdangos konstrukcijos. Fasadai padengti anuo metu madingu „,samanèlès“ tinku. 


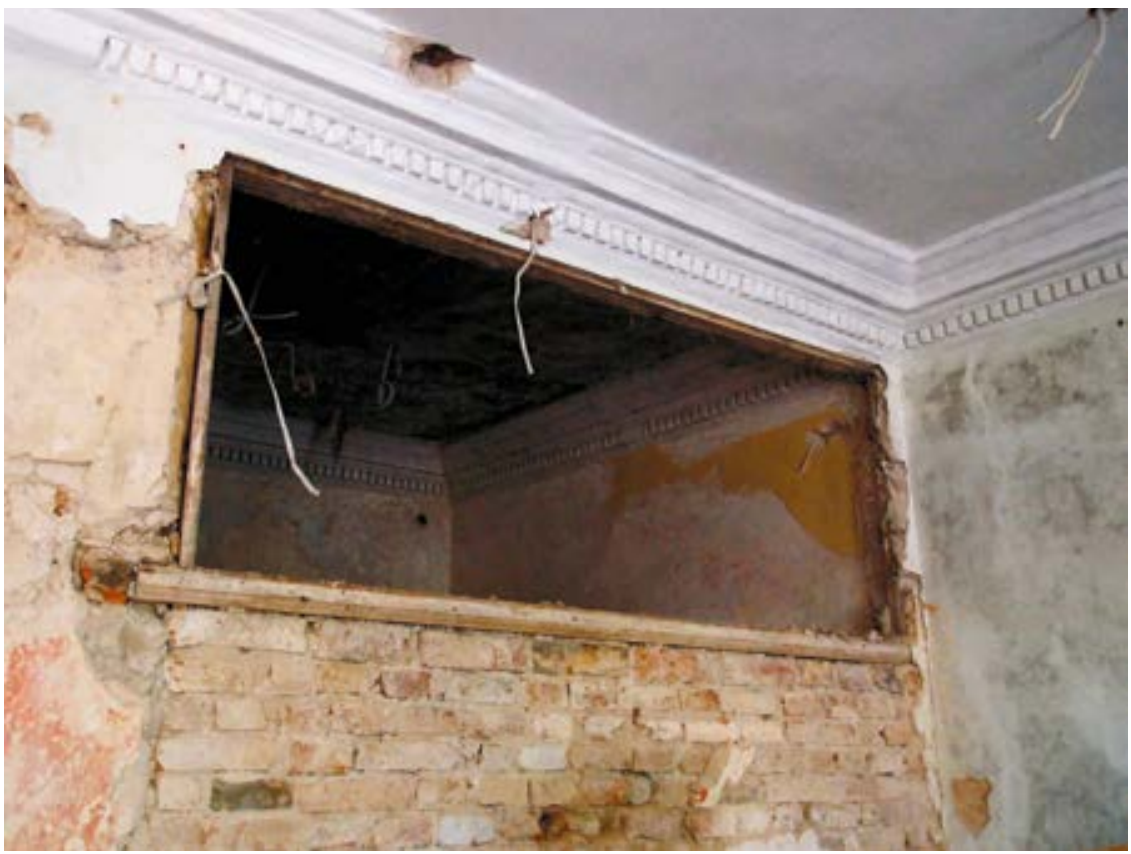

23.

Pertvara su palubės karnizu tarp 1-03 ir 1-07 kambarių. Sienutè su lango anga sumūryta vieno $\mathrm{XX}$ a. vidurio

Wall with a ceiling cornice between rooms 1-03 and remontu metu. Gilumoje matyti 1-07 kambario palubès 1-07

karnizai, Evaldo Purlio nuotrauka, 2013

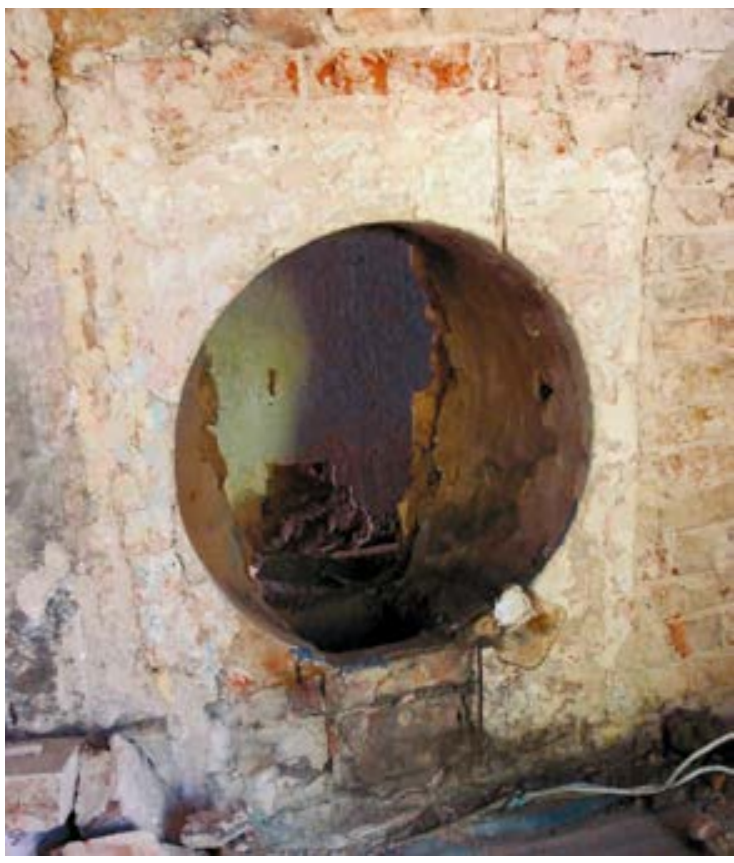

24.

Apvalus židinys 1-03 kambario šiaurinèje sienoje netrukus atidengus jo liekanas. Siena ties židiniu, iki jị užmūrijant, buvo storesnè. Nuotraukoje matyti virš židinio buvusio karnizèlio žymès, o po židiniu - ertmè pelenams su metalinių durelių staktelès atspaudais sienos plokštumoje. Židinys užmūrytas vieno $\mathrm{XX}$ a. vidurio remontų metu, Evaldo Purlio nuotrauka, 2013

Round fireplace in the northern wall of room 1-03 soon after exposing its remains 


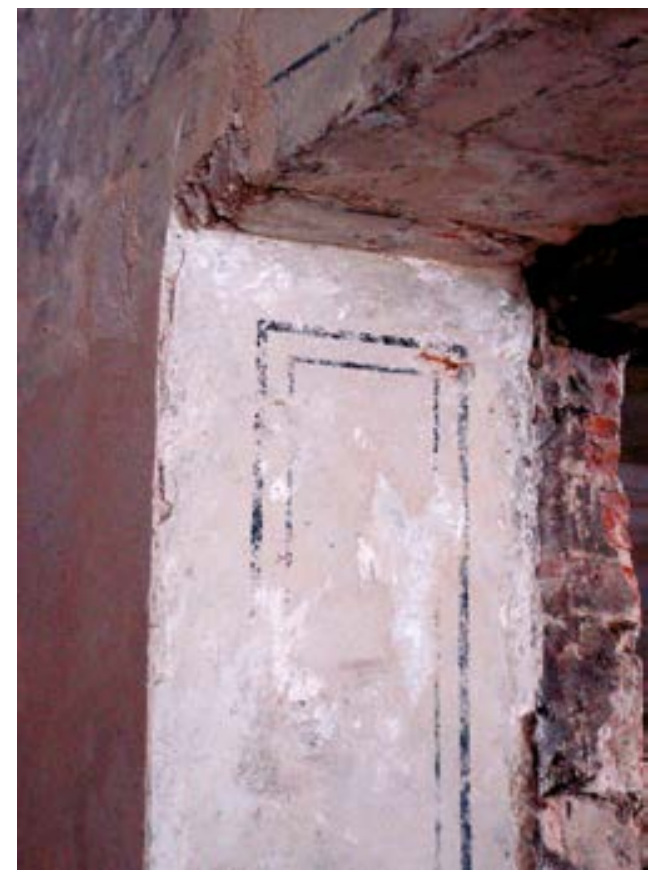

25.

Medinio angokraščio įsprūdas ir apvadą imituojantis dekoras pietinio fasado lange tarp 4 ir 5 ašių, Evaldo Purlio nuotrauka, 2014

Panel of a wooden door reveal and décor imitating a surround on the window of the south façade between axes 4-5

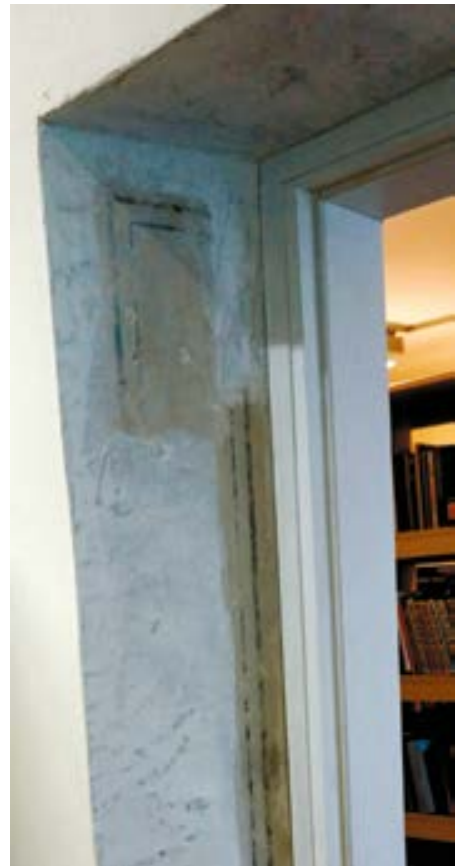

26.

Eksponuojamas medinio durų angokraščio ịsprūdas ir apvadą imituojantis dekoras, Dariaus Saltono nuotrauka, 2020

Display of a wooden door reveal and décor imitating a surround on the window 

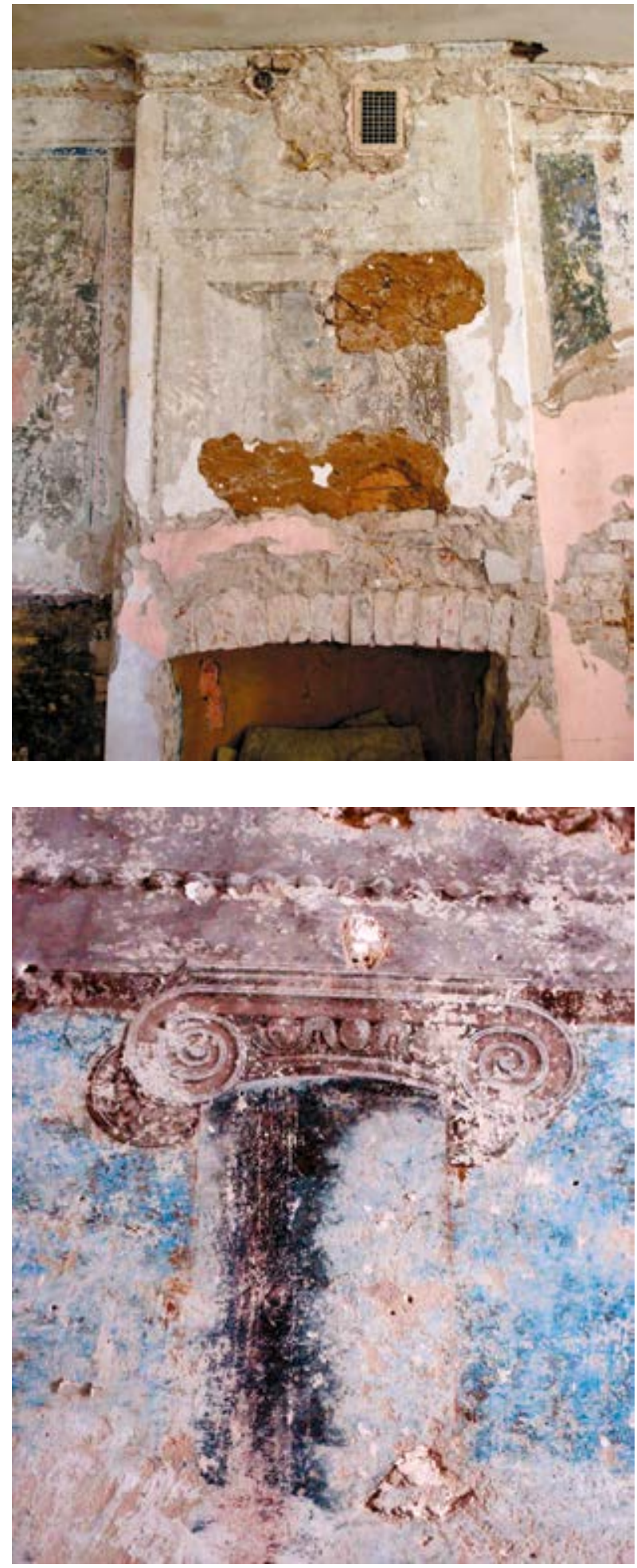

27.

Židinys 1-14 kambario šiaurinèje sienoje su tapytu dekoru virš židinio angos. Abipus židinio matyti to dekoro fragmentai. Tarp židinio angos ir tapyto dekoro likusios iškilaus karnizèlio žymès, Evaldo Purlio nuotrauka, 2013

Fireplace in the northern wall of room 1-14 with painted décor above the fireplace opening

28.

1-13 kambario vakarinès sienos tapytu kolonu fragmentas, Evaldo Purlio nuotrauka, 2014

Detail of the painted columns of the western wall 1-13 


\section{2-2014 m. rekonstrukcija, rūmų pritaikymas Leipalingio}

bendruomenès centro veiklai. Rengiant rūmų tvarkybos ir pritaikymo projektą, planuota maksimaliai atskleisti klasicistinę rūmų fasadų architektūrą, taip pat XIX amžiuje per du raidos etapus suformuotą plano struktūrą. Padaryti tai nebuvo labai sudètinga, tačiau jau projektuojant reikėjo reaguoti i pritaikymo naujai paskirčiai reikalavimus. Gerai, kad buvo reaguojama i naujienas, atsiskleidusias tyrinėjant pastatą jau prasidėjus statybos darbams (kelios svarbios rūmų patalpos iki pat statybos darbų buvo naudojamos ivairiai paskirčiai, neprieinamos tyrinètojams). Atsiradus nemažai projekte nenumatytų darbų, projektas koreguotas, nenumatytiems darbams skirtas papildomas finansavimas, taip atsirado ir vadinamieji baigiamieji rekonstrukcijos darbai. Vis dar tikimasi ir laukiama lèšų kambario su polichrominiu dekoru tvarkybai. Gal tada pavyks sutvarkyti ir gražiają rozetę ant 110 kambario lubų, atidengti daugiau dekoro, buvusio ant langų ir durų angokraščių.

2012-2014 m. pirmykščius dydžius atgavo sovietmetyje deformuotos durų angos, užmūrytos beveik visos vẻlesnių pertvarkymų metu iškirstos durų angos, pašalinti gelžbetoniniai laiptai ị antrą aukštą ir kt. Pašalinus šiuos laiptus atkurta vestibiulio erdvė bei didžioji dalis vestibiulio sienose buvusių architektūrinių elementų. Kaip minèta, diktuojant pritaikymo naujai paskirčiai reikalavimams ne tokie kaip buvo suprojektuoti naujieji laiptai, nepavyko užmūryti kelių îvairiu laiku iškirstų durų angų. Nepavyko ir iš vieno puošniausių, spalvingiausių rūmų kambarių iškelti sanitarinių ir techninių ịrenginių.

Bene labiausiai matomas rekonstrukcijos padarinys - $i$ angas sugrịžę klasicistinio piešinio langai, nauja skarda perdengtas stogas, atidengtos ir restauruotos kolonų portikuose bazès. Iki šiol jų liekanas dengè grubiai užlietas betonas. Langai, kaip ir buvo nuo pirmosios rūmų rekonstrukcijos (iki sovietmečio), i̇statyti fasadų plokštumoje. Deja, nepasinaudota žinia apie raudoną pirminių grindų po portiku plytelių spalvą ir dydi bei portiko grindis juosusi apvadą iš granito plokščiu - beveik visos apvado plokštès iki prasidedant baigiamiesiems darbams jau buvo atidengtos. Apvado ir raudonų grindų likučiai uždengti banaliom, turbūt už mažiausią kainą nupirktomis pilkšvomis akmens masės grindų plytelemis.

$97-2020$

Acta Academiae Artium Vilnensis 


\section{Grūdų sandèlis}

Žiūrint ị dvaro ansamblị po sovietmečio pertvarkymų, atrodè, kad rūmai susidejo iš dviejų daugmaž vienu metu statytų dviaukščių korpusų, sujungtų vienaaukščiu intarpu. Klaidino padidinti buvusio grūdų sandèlio langai, ypač puošnūs tokie pat kaip rūmų pagrindiniame fasade keturių kolonų portikai prie grūdų sandèlio galinių fasadų. Pritaikant pastatus mokyklai, padaryti architektūros pertvarkymai užmaskavo grūdų sandèlio, taip pat ir ansamblio architektūros unikalumą. XIX a. pabaigoje - XX a. pradžioje projektuojant grūdų sandèlį derintasi prie klasicistinės rūmų architektūros, stengtasi sukurti vieningo stiliaus ansambli. Laikas tam buvo palankus, nes dar kartą susidomèta klasikine architektūra. Statytoją akivaizdžiai trikdè ir, matyt, jam atrodè, kad senas didelis ūkinès paskirties pastatas šalia klasicistinių rūmų menkina jo prestižą. Ir jis buvo nugriautas. Liko didelis skliautuotas rūsys storomis iš akmenų mūrytomis sienomis. Ant senų pamatų statyto pastato paskirtis nedaug tepasikeitè, tačiau kaip pasikeitè jo vaizdas - turbūt nèra Lietuvoje ūkinès paskirties pastato, taip primenančio amfiprostylos tipo graikų šventyklą.

Ant kokio pastato pamatu pastatytas grūdu sandèlis? Atsakymo ị ši klausimą vis dar neturime. Grūdų sandèlis pastatytas ant kažkokio didelio, seno, gal net senesnio už klasicistinius rūmus pastato pamatų. Išliko didelis skliautuotas su trimis stulpais išilginèje ašyje rūsys. Vienintelis įèjimas, tiksliau ịvažiavimas ị rūsị buvo pietiniame pastato gale [29 il.]. Vartai buvo dvivèriai, be staktos, atidaromi ị vidų. Iš ko buvo pastatyta statinio virš didžiojo rūsio antžeminè dalis, kam ji buvo skirta ir kodèl iš tikrujų ji buvo perstatyta, vis dar nežinome. Nevienodas rūsio rytinès sienos storis perša mintị, kad senojo pastato antžeminès dalies išorinis kontūras buvo su kažkokia iškiša rytiniame fasade. Visose keturiose rūsio sienose - nedideli grotuoti langeliai. Rūsio sienos mūrytos iš natūralių ir skaldytų lauko akmenų. Tik langelių ir ịvažiavimo vartų angokraščiai formuoti iš plytų. Plytos raudonos, jų dydis svyruoja apie $30 \times 7 \times 15 \mathrm{~cm}$. Rūsio mūrų kapitalumas perša mintị apie ne mažiau kapitalią pastato antžeminę dalį.

Neoklasicistinio grūdų sandèlio statyba. Išskirtinès architektūros grūdų sandèlis statytas neoklasicizmo stiliumi. Pastato architektas kol 


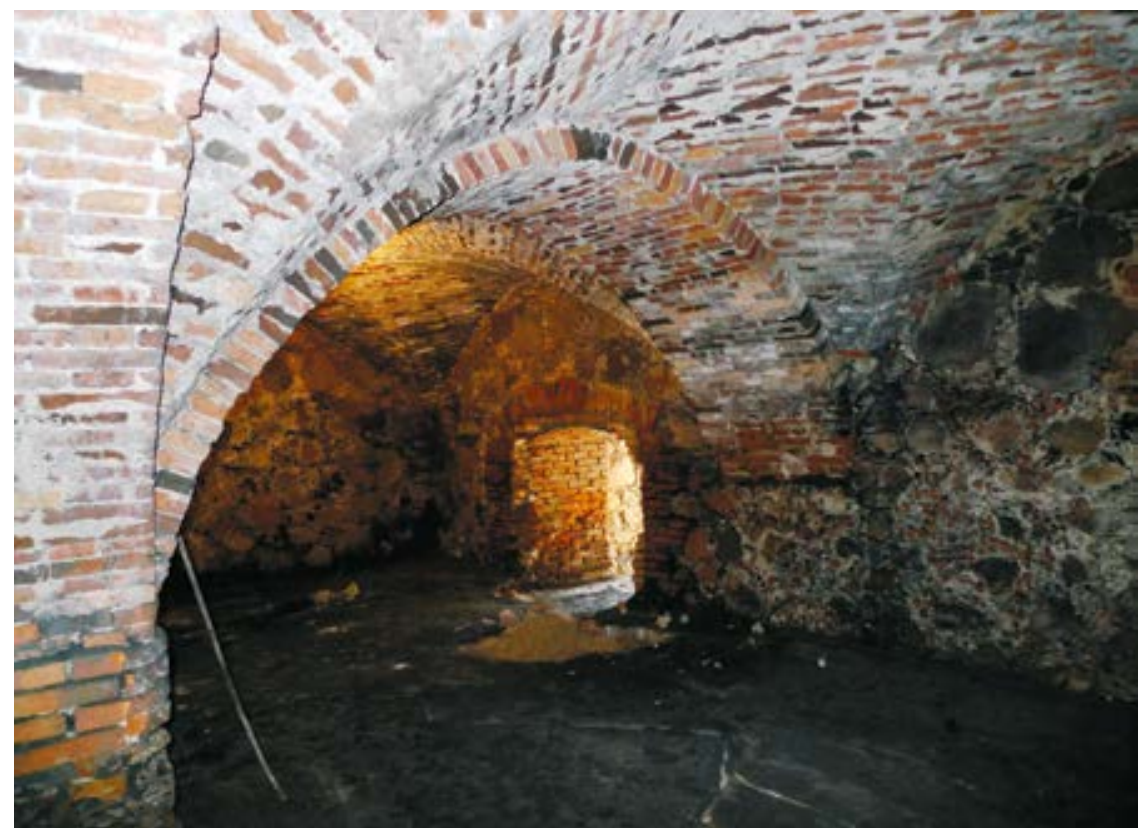

29.

kas nežinomas, nors tikètina, kad tai buvo pats savininkas, inžinierius ir architektas Petras Balinskis arba jo brolis architektas Antanas Balinskis (1863-1913) ${ }^{32}$. Senojo pastato, galbūt taip pat grūdų sandèlio, perstatymas aiškiai susijęs su Balinskio užmojais įrengti dvare prašmatnią rezidenciją. Senasis pastatas greičiausiai nelabai derèjo prie klasicistinès rūmų architektūros, dar labiau jis, matyt, netiko prie planuojamo būsimojo dvaro vaizdo. Ant nugriauto pastato rūsio, vietomis pasirenkant net šiek tiek abejotinus konstrukcinius sprendimus, pastatytas statinys su kolonomis galiniuose fasaduose. Išsaugotas ir šiek tiek patobulintas senasis įvažiavimas ị rūsị, o patobulinti ji reikèjo dèl to, kad virš ịvažiavimo ị rūsị skliauto turèjo užvažiuoti vežimai, atvežantys derlių prie pagrindiniame grūdų sandèlio fasade už portiko su keturiomis kolonomis įrengtų durų. Pietinio portiko kolonoms padarytas naujas pamatas. Kažkodèl to nepadaryta šiauriniame gale - čia

32 Už šią mintị apie galimą architektą ir internetinę nuorodą apie Antano Balinskio projektuotus pastatus (http://www.polskipetersburg.pl/instytucja/kirocznaja-ul-nr-41) nuoširdžiai dèkoju dailès istorikei Rūtai Janonienei. 
kolonos sumūrytos ant rūsio sienos, o pastato šiaurinè siena - ant rūsio skliauto. Ant skliauto, nesiderinant prie rūsio stulpų ritmo, buvo pastatyti ir mūriniai grūdų sandèlio medinę perdangą laikantys stulpai sandèlio vidurinėje ašyje. Sovietmečiu medinè perdanga buvo pakeista gelžbetonine. Nežinia, ar dèl šių grūdų sandèlio sprendinių, ar dèl negrabiai prie pat rūsio stulpo prieš 1973 m. padaryto katilinès kamino pamato bei padidejusio pirmo aukšto perdangos svorio, rūsio skliautuose atsirado dideli plyšiai.

Priekiniame ir galiniame grūdų sandèlio fasaduose abiejuose aukštuose buvo keturios didelès durų angos kroviniams su derliumi įnešti [30, 31 il.]. Durys antrame aukšte netgi platesnès. Maišai su derliumi, matyt, buvo pakeliami skridiniu ar skrysčiais. Virš antro aukšto durų angų dar gali atsirasti konstrukcijos, laikiusios skridinius, žymės ar likučiai. Laiptai, jungę du grūdų sandèlio aukštus, buvo mediniai, ịkomponuoti dešinèje pusèje prie pietinio įėjimo ị pirmą aukštą [32 il.], kairèje pusèje, pietvakariniame kampe, buvo atitverta nedidelè patalpèlè. Apie galimai priešais, šiaurès vakariniame kampe, buvusius antruosius laiptus žinių neturime. Medinę perdangą virš antro aukšto laikè išorinès sienos ir vidurinėje išilginėje ašyje pastatyti mediniai stulpai. Grūdų sandèlio fasadai buvo padengti rustuotu tinku, o abiejų aukštų patalpų sienų paviršiai liko atviro plytų mūro, netinkuoti, padažyti kalkèmis. Kalkėmis dažytose sienose galima ịžiūrèti laiptų ir nedideles patalpėles nuo didžiosios erdvės atskyrusių pertvarų žymes. Sienų vidinė pusė nutinkuota tik grūdų sandèli pritaikius mokyklai.

Grūdų sandèlio pritaikymas mokyklai. Buvę dvaro rūmai netenkino mokyklos poreikių. Ne visai aišku, kada - veikiant dvaro rūmuose mokyklai 1923-1935 m. ar vèl juose ịkūrus mokyklą 1946 m. - mokyklos poreikiams panaudotas ir grūdų sandèlis. Maži grūdų sandèlio langeliai mokymo įstaigai netiko. 1956 m. nuotraukoje [33 il.] matome langelius jau padidintus. Tyrimai atskleidè, kad formuojant nuotraukoje užfiksuoto dydžio langus stengtasi išsaugoti langų sąramas, pasinaudoti jomis, o platinant angas buvo nutašytos tik užkarpos staktoms. Angu plotis liko mažesnis nei mūrinės sąramos ilgis. Kitaip buvo didinant langus prieš 1973 metus. Gerai, kad visos pirminès langelių sąramos, tiksliau, sąramų viršutinè dalis, išliko ir dabar aiškiai rodo pirminių grūdų langelių komponavimą pirmo ir antro aukštų sienose.

Evaldas Purlys — Leipalingio dvaro pastatu raida: žvalgomuju architektūros tyrimu ir restauravimo duomenys 
Išsiaiškinti langų, suformuotų kuriantis mokyklai, formas padejjo kelios tiriant pastatą rastos užmūrytos langų angos. Ant jų angokraščių liko nemaži plotai angokraščiu tinko ir keli staktų atspaudų fragmentai. Gerokai neiprasta pokario darbams tinko sudètis - jame nesimato cemento požymių. Kol kas tai vienintelis argumentas, peršantis mintị, kad langeliai galëjo būti padidinti tarp 1923-1935 m. arba prieš 1946 m., kai buvo ruošiamasi atkurti mokyklą, o tolimuose Lietuvos kampeliuose cementas dar galëjo būti mažai naudojamas.

Mokyklos planu tobulinimai XX a. antroje pusèje. Anksčiau minèti 1973 m. apmatavimai ir $1980 \mathrm{~m}$. tyrinèjimai iki $1973 \mathrm{~m}$. vykusios rekonstrukcijos datos nepatikslina, tačiau aiškiai nusako buvusio grūdų sandèlio rekonstrukcijos mastą. Didieji pastato pertvarkymai padaryti tarp $1956 \mathrm{~m}$. ir 1973 metų. Medinė pirmo aukšto perdanga pakeista gelžbetonine, ịrengiant sporto salę pašalinta antro aukšto perdanga ir ją laikę mediniai stulpai, rūsyje ịrengta katilinè su sandèliu anglims, pakeista ịejimo ị rūsį angos vieta. 1956 m. nuotraukoje grūdų sandèlio langai jau ne pirminių formų, bet dar nedideli. Iki $2019 \mathrm{~m}$. išsilaikę pastato planai bei fasadų vaizdai vèliausiai užfiksuoti $1973 \mathrm{~m}$. apmatavimų brěžiniuose ${ }^{33}$. Planai nepakitę ir $1980 \mathrm{~m}$. brèžiniuose - ,apart klasių, kurios įrengtos pirmame aukšte, antrame aukšte yra sporto salè ${ }^{{ }^{3} 34}$. Pastoliai prie pastato vienoje iš 1987-1989 m. nuotrauku reiškia, kad tuo metu buvo tvarkomi fasadai - atrodo, šios rekonstrukcijos metu fasadai padengti anuo metu madingu „samanèlès“ tinku. Viduje šiuokart apsiribota paprastu remontu.

2019-2020 m. restauracija. Grūdų sandèlio pirminès langų formos paieška kaip reta iliustruoja architektūrinių tyrimų tvarkybos darbų svarbą restauruojant pastatų architektūrą. Žvalgomuju buvusio grūdų sandèlio tyrimų metu buvo surasti pirminiu pirmo ir antro aukštų langu sąramų likučiai, tačiau tikrosios šiu langų formos nustatytos tik prasidejjus statybos darbams. Po sovietmečio rekonstrukcijų buvo likusi tik langelių sąramų viršutinè dalis ir keli užmūryti, kaip tada atrodè, mažai pakeisti langai. Kuriantis mokyklai jie buvo dar nedaug padidinti. $2010 \mathrm{~m}$. parengtame projekte grūdų sandèlio architektūra su šiais langais net neprimena grūdų sandèlio, be to, jie panašiai ir suskaidyti. Toliau tiriant tikètasi didesnių ar

33 LTSR KŪM komunalinio ūkio projektavimo institutas, Druskininkų skyrius, Leipalingio vidurinės mokyklos II ir III korpusai. Apmatavimų brèžiniai. Kompl. / obj. Nr. 649/1, 1973.

34 LTSR KŪM komunalinio ūkio projektavimo institutas, Druskininkų skyrius, Leipalingio vidurinè mokykla. Tyrinėjimai. Obj. Nr. 69.25, 1980. 


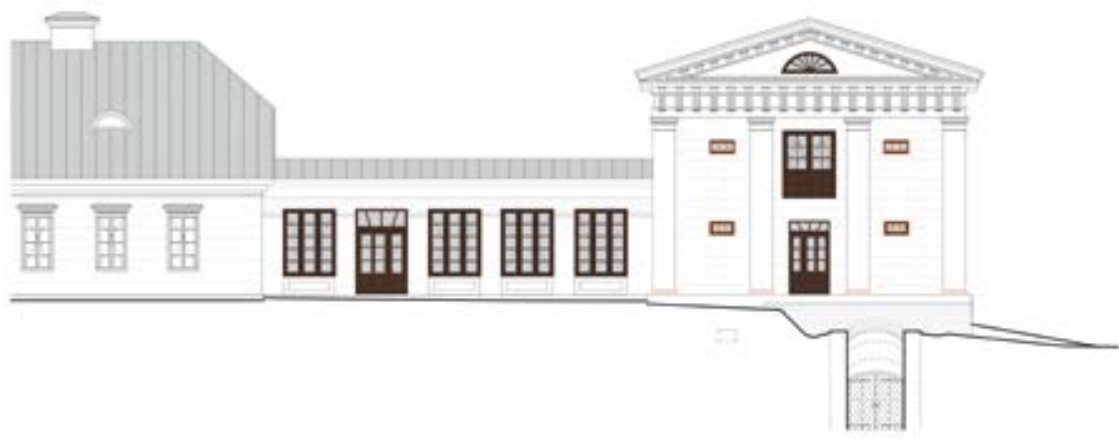

30.

Oranžerija ir grūdų sandèlis dvaro ansamblio pietinio fasado brèžinyje, braižė Darius Saltonas, 2020
Orangery and a grain storage in a drawing of the south façade of the manor ensemble

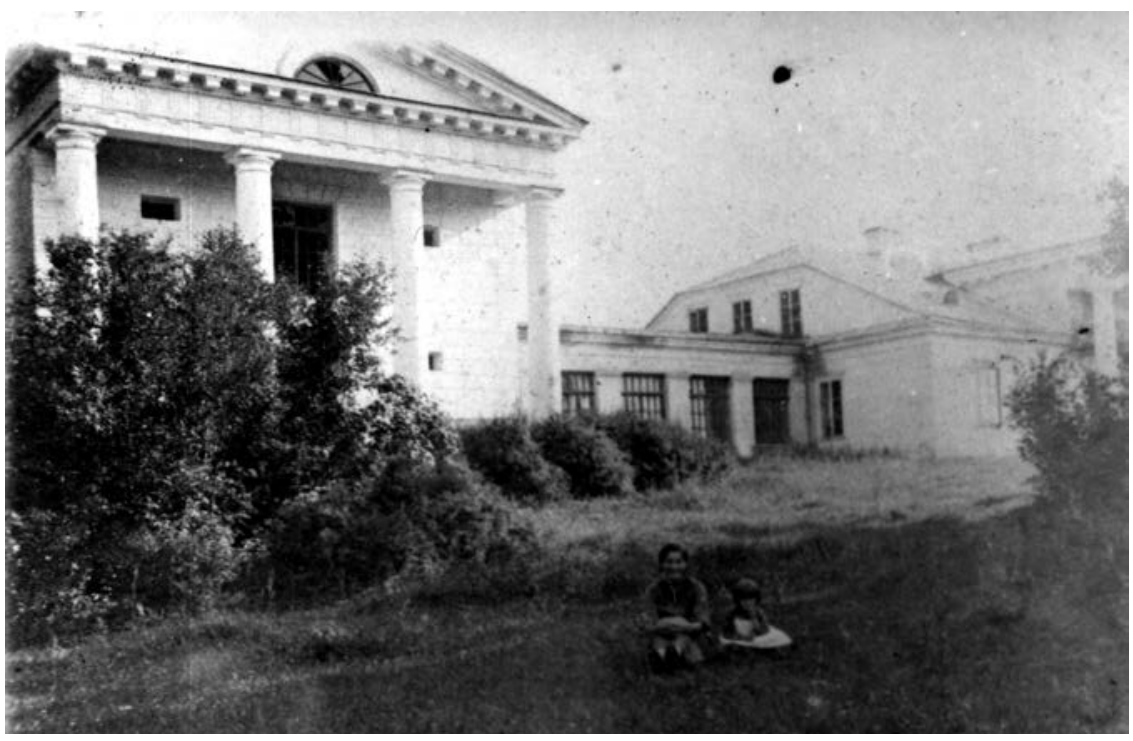

31.

Grūdų sandèlio ir oranžerijos šiaurinè pusė $1928 \mathrm{~m}$. Sandèlio langeliai dar nepadidinti. Remiantis šia nuotrauka galima rekonstruoti langų piešinį oranžerijos ir grūdų sandèlio angose, mokytojo A. Matulionio nuotrauka, originalas saugomas Leipalingio progimnazijos Algirdo Volungevičiaus kraštotyros muziejaus fonduose
Northern side of the grain storage and the orangery in 1928. The windows of the storage are not enlarged yet

Evaldas Purlys — Leipalingio dvaro pastatu raida:

žvalgomuju architektūros tyrimu ir restauravimo duomenys 


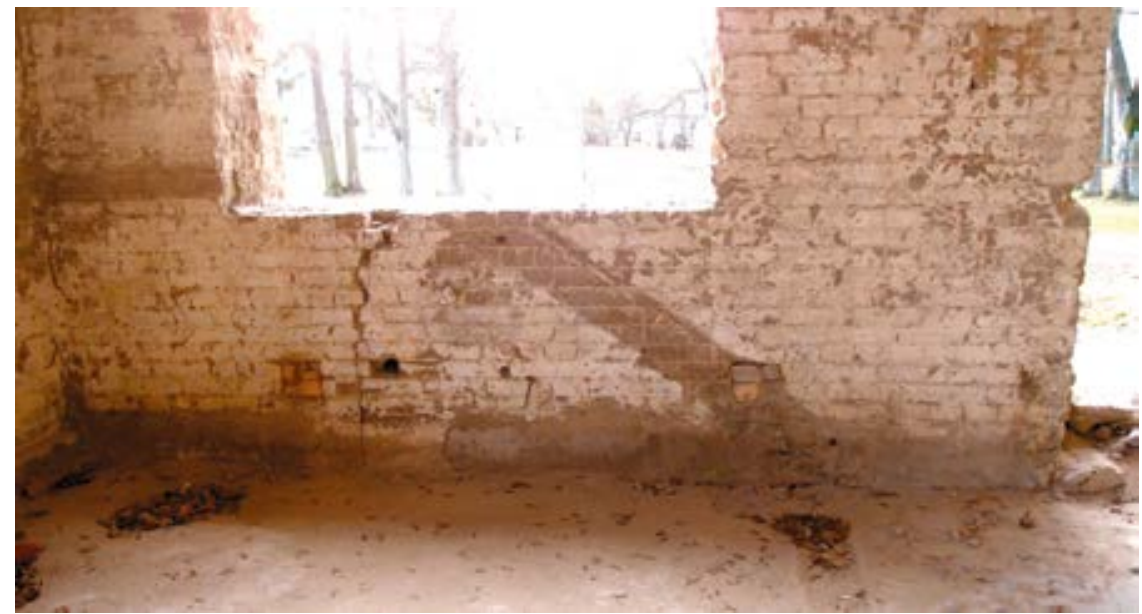

32.

Laiptų su aikštele ị viršutinị grūdų sandèlio aukštą konstrukcijos žymės buvusio sandèlio pietinėje sienoje, Evaldo Purlio nuotrauka, 2019
Marks of the construction of a stairway with a landing to the top floor of the grain storage in the southern wall of the former storage

mažesnių jụ pločio, ypač aukščio, patikslinimų, tačiau ne tokių, kokie pasirodè natūroje. Grūdų sandèlio laikotarpio langų dydžiu ir formų požymiai slypejjo mūru gilumoje, ir juos surasti buvo galima tik pradejjus rekonstrukcijos darbus, išėmus sovietmečiu ịstatytų langų staktas, nuardžius to meto angokraščius formavusị silikatinių plytų mūrą.

Grūdų sandèlio langeliai buvo 5-7 plytų eilių (apie $43 \mathrm{~cm}$ ) aukščio, 95-85 cm pločio išorẻje, su šiek tiek siaurẻjančiais link staktos angokraščiais ir staktomis sienos gilumoje. Suradus 119 langelį, kuris buvo užmūrytas statant oranžeriją, iš dalies ji atidengus pasimatè ne tik jo vidiniai angokraščiai, bet ir staktos atspaudai. Taip ir buvo nustatyta, kad stakta buvo $40 \mathrm{~cm}$ aukščio, apie $85 \mathrm{~cm}$ pločio, o ị angą ji buvo ịstatyta mūrijant angokraščius. Staktoje buvo įtvirtinti trys vertikalūs metaliniai grotų virbai.

Darbų užsakovas - Druskininkų rajono savivaldybès administracija ir KPD Alytaus teritorinis padalinys - palankiai reagavo ị darbų metu atsidengusias grūdų sandèlio architektūros naujienas, leido koreguoti fasadụ projektą, restauruoti didžiają dalị mažujų grūdų sandèlio langelių. Didesni $2010 \mathrm{~m}$. numatytos formos langai palikti tik darbo kambariuose, vestibiulyje 


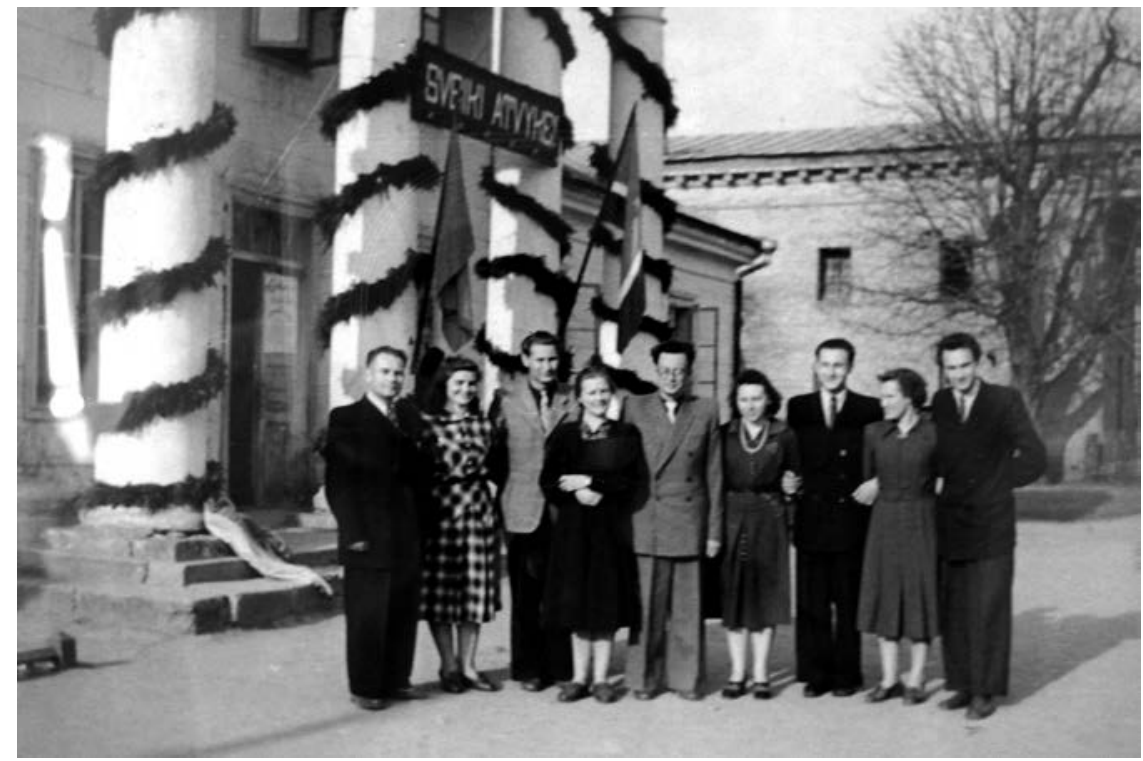

33.

Mokytojų grupè prie įejjimo ị buvusius rūmus, fotografuota $1956 \mathrm{~m}$. mokyklos dešimtmečio proga, už jų - buvęs grūdų sandèlis su pirmą kartą padidintais langais, nuotraukos originalas saugomas Leipalingio progimnazijos Algirdo Volungevičiaus kraštotyros muziejaus fonduose
Group of teachers at the entrance to the former manor, photographed on the occasion of the school's $10^{\text {th }}$ anniversary in 1956. Behind them is the former grain storage with the windows enlarged for the first time

[34 il.]. Jau restauruota sovietmečiu nukapota fasadų rustika, ruošiamasi atkurti triglifus ir kitas antablemento detales [35 il.]. Rustika restauruota atsižvelgiant ị šiauriniame fasade išlikusios rustikos piešinį, rustų eiliavimą.

Buvusio grūdų sandèlio antrame aukšte, kaip ir buvo, numatyta irrengti koncertų ir ịvairaus pobūdžio renginių salę, tik nuo šiol į ją bus galima pakilti dviem laiptais. Salès galuose planuojama ịrengti antresoles žiūrovams. Daug dėmesio skiriama priešgaisrinėms priemonėms - gaisrininkų ir neiggaliujų reikalavimai, kaip ir daugelyje kitų kultūros paveldo objektų, turi įtakos architektūros sprendiniams. Jau sutvirtinta stogo ir šonines sienas veržianti konstrukcija, pakeista stogo danga ir pan., liejamos naujos konstrukcijos. Dideliame skliautuotame su atviro mūro sienomis ir skliautais rūsyje bus rengiamos ịvairaus pobūdžio parodos. Darbus planuojama baigti $2021 \mathrm{~m}$. pradžioje. 


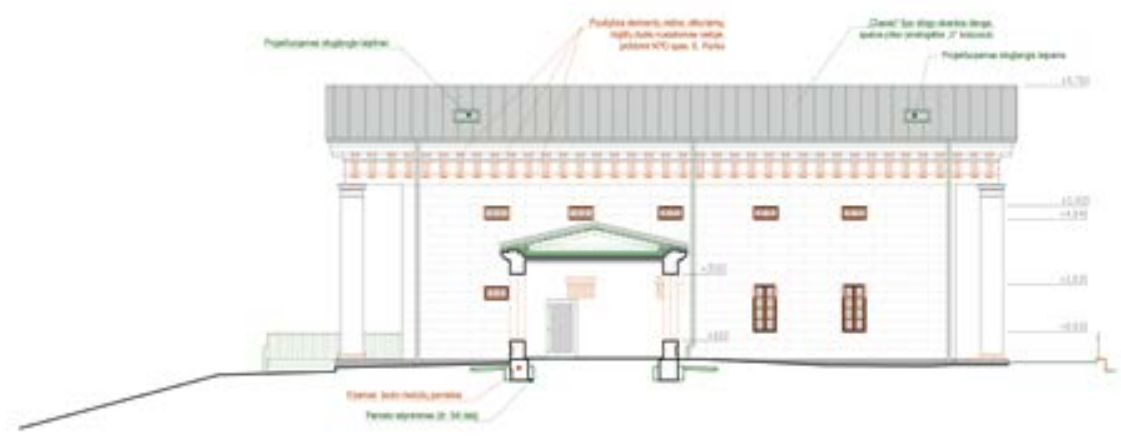

34.

Grūdų sandèlio vakarinio fasado restauravimo projektas. Vienas iš pirmo aukšto langų buvo padidintas iki 1956 m., užfiksuotas $1956 \mathrm{~m}$. nuotraukoje. Išliko dar kartą nepadidintas rekonstrukcijos, vykusios prieš 1973 m., metu, braižè Darius Saltonas, 2020
Project of the conservation of the west façade of the grain storage. One of the ground-floor windows was enlarged before 1956

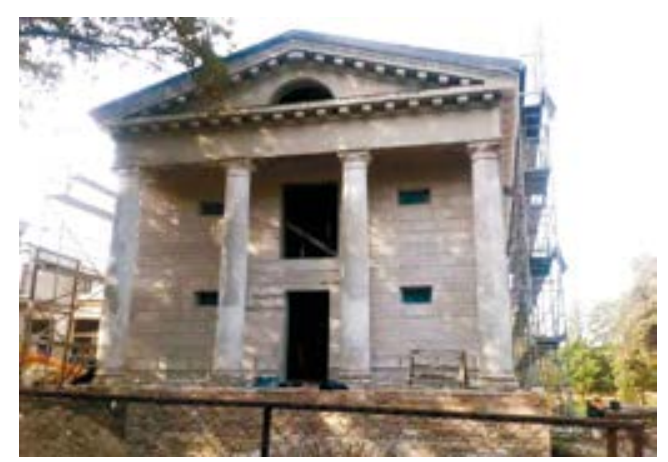

35.

Buvusio grūdų sandèlio pietinis fasadas restauravimo metu $2020 \mathrm{~m}$. spalio mėn. Dar nesuformuoti triglifai ir profiliuota juosta po jais, Dariaus Saltono nuotrauka, 2020

South façade of the former grain storage during conservation in October 2020 


\section{Oranžerija}

Dvaro rūmų ansamblyje šis statinys iškilo vèliausiai. 1905 m. nuotraukoje [žr. 31 il.] oranžerijos šalia dvaro rūmų dar nėra. Deja, ši nuotrauka nepasako, ar tuo metu jau stovèjo neoklasicistinis grūdų sandèlis. Perstatytas, graikų šventyklą primenantis grūdų sandèlis kurị laiką stovejjo atskirai, nesujungtas su rūmais. Statant grūdų sandèlị, matyt, dar neplanuota statyti oranžerijos, todèl sumanius ją statyti teko užmūryti du grūdų sandèlio pirmo aukšto langus. Oranžerijoje suformuoti dideli langai, abiejose jos pusėse padarytos plačios durys, jungusios abipus dvaro ansamblio buvusio parko dalis. Durų, kaip dabar jungiančių oranžeriją su rūmais ar grūdų sandèliu, nebuvo. Oranžerijos perdanga akermano tipo, tik čia vietoj plytų skliauteliams tarp metalinių sijų panaudotas betonas. Sienos iš betoninių plytų, kaip ir grūdų sandèlio mūruose. Lubos bei sienos ir čia liko netinkuotos, padažytos kalkèmis.

Oranžerija buvo pastatyta neįvertinus gruntų po pastatu savybių, prie grūdų sandèlio ėmė „sėsti“ abiejų oranžerijos sienų pamatai. Teko ne tik tvirtinti pamatus, bet ir permūryti du tarplangius. 2019-2020 m. îstatyti nauji buvusios oranžerijos langai ir durys, sumontuota nauja stogo konstrukcija, pakeista stogo danga.

\section{Apibendrinimas}

2012-2014 m. darbais baigèsi taip ir neįsikomponavusios i buvusius dvaro rūmus, grūdų sandèlį ir oranžeriją mokyklos veiklos laikotarpis, prasidèjo naujas Leipalingio administracinių ir kultūrinių įstaigu gyvenimo šiuose statiniuose laikas. Rūmuose jau padaryti projekte numatyti statybiniai darbai, įrengtos šiuolaikinès inžinerinès sistemos, $2014 \mathrm{~m}$. pabaigoje i rūmus ịsikèlė aukščiau išvardytos įstaigos. Buvusio grūdų sandėlio pertvarkymo darbai prasidèjo tik 2019 m., po ilgu biurokratinių parengiamujų darbų gavus finansavimą. Užbaigti šių statinių dalinės restauracijos, pertvarkymo darbus planuojama $2021 \mathrm{~m}$. pradžioje.

Nè vienas dvaro pastatų nebus toks, koks buvo dvaro funkcionavimo metu. Pastatų struktūra bus tokia, kokią padiktavo apie 2010 m. projektui suformuluoti poreikiai. Prieš 1973 m. buvusiame grūdų sandèlyje 
irrengta salė bus modernizuota, patobulinta, buvusi oranžerija, funkcionavusi su atskirais iejjimais iš lauko, taps koridoriumi, jungiančiu salę su patalpomis rūmuose. Vienu svarbiausių paminklotvarkos uždavinių tvarkant pastatus buvo vulgarių XX a. antros pusès antsluoksnių nuėmimas. Iš dalies atidengtos, atskleistos XIX a. ir XX a. pradžioje susiformavusios dvaro pastatų vertingosios savybės, pirmykščius dydžius atgavo kone visos svarbiausios rūmų erdvès, o formas ir piešini - langai. Pastarieji iš esmès pakeitè, atkūrè ir buvusio grūdų sandèlio vaizdą. Nors ne visi jie atgavo pirmykščius dydžius ir formas, grūdų sandèlis, ūkinès paskirties pastatas, vèl demonstruoja savo architektūros unikalumą, išskirtinumą, statybos laiku gyvenusių žmonių įsivaizdavimus, architektūros madą. Dvaro teritorijos ir parko raidos nagrinëjimui turètų būti skirta atskira studija, atskiras straipsnis. Laukia dar nemažai neatidèliotinų darbų bei naujų dvaro ir dvaro sodybos istorijos šaltinių paieškų, dvaro pastatų architektūros ir jos raidos studijų.

Gauta 20201105 


\section{Šaltiniai}

Jarmalienė Gražina, Mokyklos pastato Alèjos g. 30 Leipalingio mstl., Druskininkų sav., pritaikymas bendruomenès centro veiklai, Leipalingio dvaro sodybos rūmai UK 15827, Techninio projekto korektūra - laida „B“, 2014, in: Druskininkų savivaldybės administracijos archyvas.

KPD Nekilnojamojo kultūros paveldo vertinimo tarybos 20190711 aktas Nr. KPDRM-1125/2, p. 23, in: Evaldo Purlio asmeninis archyvas.

LTSR KŪM komunalinio ūkio projektavimo institutas, Druskininkų skyrius, Leipalingio vidurinės mokyklos II ir III korpusai. Apmatavimų brèžiniai. Kompl. / obj. Nr. 649/1, 1973, užsakovas Lazdijų rajono liaudies švietimo skyrius, in: Druskininkų savivaldybès administracijos archyvas; Leipalingio progimnazijos Algirdo Volungevičiaus kraštotyros muziejus.

LTSR KŪM komunalinio ūkio projektavimo institutas, Druskininkų skyrius, Leipalingio vidurinè mokykla. Tyrinėjimai. Obj. Nr. 69.25, 1980, užsakovas Lazdijų rajono liaudies švietimo skyrius, in: Druskininkų savivaldybės administracijos archyvas; Leipalingio progimnazijos Algirdo Volungevičiaus kraštotyros muziejus.

Mokyklos pastato Alejjos g. 30 Leipalingio mstl., Druskininkų sav., pritaikymas bendruomenès centro veiklai, Kultūros paveldo objekto tvarkybos darbų projektas. Projekto vadovas Darius Saltonas, projekto dalies vadovas Evaldas Purlys, 2011. Užsakovas Druskininkų savivaldybės administracija, in: Druskininkų savivaldybès administracijos archyvas.

Purlys Evaldas, Mokyklos pastato Alejos g. 30 Leipalingio mstl., Druskininkų sav., pritaikymas bendruomenès centro veiklai. II etapo architektūriniai tyrimai, 2010. Užsakovas UAB „Consena“, in: Druskininkų savivaldybès administracijos archyvas.

Purlys Evaldas, Leipalingio dvaro sodyba (Atv 856), Dvaro rūmų vakarų (V) korpusas.
Architektūriniai tyrimai tvarkybos darbų metu, 2014. Užsakovas UAB „Avona“, in: Druskininkų savivaldybès administracijos archyvas.

Reitelaitis Jonas, Leipalingio dvaro 1685 m. inventoriaus vertimas ir paaiškinimai, in: Istorinių dokumentų apie Leipalingị vertimų byla, in: Leipalingio kraštotyros muziejus, Dariaus Saltono, Evaldo Purlio asmeniniai archyvai.

Saltonas Darius, Mokyklos pastato Alejjos g. 30

Leipalingio mstl., Druskininkų sav., pritaikymas bendruomenès centro veiklai. Istoriniai ir ikonografiniai tyrimai, 2010. Rengejas UAB „Consena“, in: Druskininkų savivaldybès administracijos archyvas.

Saltonas Darius, Dobožinskaitè Glaudina, Mokyklos pastato Alèjos g. 30 Leipalingio mstl., Druskininkų sav., pritaikymas bendruomenès centro veiklai. Architektūriniai tyrimai, 2010, in: Druskininkų savivaldybės administracijos archyvas.

Trečiokienė Verutè, Mokyklos pastato Alejjos g. 30 Leipalingio mstl., Druskininkų sav., pritaikymas bendruomenės centro veiklai. Pastato polichrominès analizès kūrinys tyrimai, 2010, in: Druskininkų savivaldybès administracijos archyvas.

Trečiokienė Verutè, Mokyklos pastato Alèjos g. 30 Leipalingio mstl., Druskininkų sav., pritaikymas bendruomenès centro veiklai. Leipalingio dvaro rūmų vidaus patalpu papildomi polichromijos tyrimai - II, 2013, in: Druskininkų savivaldybès administracijos archyvas; Verutès Trečiokienès asmeninis archyvas.

Trečiokienė Verutė, Leipalingio dvaro rūmų vidaus patalpu papildomi polichrominiai tyrimai - II. Patalpos 110 lubų rozetès piešinys - schema, 2013, in: Druskininkų savivaldybès administracijos archyvas. 


\section{Literatūra}

Dambrauskaitė Neringa, Lietuvos Didžiosios Kunigaikštystès bajoru namai XVIXVII a. pirmoje pusèje, Vilnius: Vilniaus universiteto leidykla, 2019.

Janušonienè Margarita, „Dailès paveldo moksliniai tyrimai ir jų reikšmė ịpaveldinimo procese", in: Acta Academiae Artium Vilnensis, Vilnius, 2015, t. 77-78: Dailes ir architektūros paveldas: tyrimai, išsaugojimo problemos ir lūkesčiai, sud. Dalia Klajumienè, p. 289-308.

Lietuvos architektūros istorija: nuo XVII a. pradžios iki XIX a. vidurio, t. II, Vilnius: Mokslo ir enciklopediju leidykla, 1994.

Lietuvos dvarai: Dviejų tomų žinynas, t. 1, sud. Ingrida Semaškaitè, Vilnius: Algimantas, 2009.

Miškinis Algimantas, Lietuvos urbanistikos paveldas ir jo vertybès. Užnemunès miestai ir miesteliai, Vilnius: Savastis, 1999.

Mūsu Lietuva: krašto vietoviu istoriniai, geografiniai, etnografiniai bruožai, paruošè Bronius Kviklys, Boston: Lietuvių enciklopedijos leidykla, t. III, 1966.

Polski Peterburg, [interaktyvus], http://www. polskipetersburg.pl/instytucja/kirocznaja-ul-nr-41. 


\title{
Summary
}

\section{The Development of the Buildings of the Leipalingis Manor: The Data of Exploratory Architectural Research and Conservation}

\author{
Evaldas Purlys
}

Keywords: Leipalingis manor (Druskininkai district), architecture, exploratory architectural research, heritage, conservation.

The article analyses the architectural development of three buildings - a manor, an orangery and a grain storage - of the Leipalingis (Druskininkai district) manor ensemble, built at a different time, which was well revealed during field research and restoration works conducted in 2010-2014 and 2019-2020. They compensated for the lack of historical data on this ensemble. Comparing the results of the architectural research with photographs held at the Leipalingis Museum provided a great deal of new information about the change of the architecture and décor elements of the manor buildings. The author of the article conducted the exploratory architectural research himself, thus many of his insights are a result of analysing the buildings in situ.

The manor ensemble suffered considerable damage in the years of World War II, and the remaining buildings were drastically restructured in the Soviet period. After the performed reconstructions, the buildings of the classicist-style manor, the neoclassicist grain storage and the orangery built in the early $20^{\text {th }}$ century were transformed into a single architectural ensemble. The one-storey orangery connected the two-storey buildings of the manor and the storage. For a long time, it confused researchers in the second half of the $20^{\text {th }}$ century and the early $21^{\text {st }}$ century. After this reconstruction, the grain storage was perceived as a wing of the manor, due to its strongly enlarged windows untypical of an auxiliary building and its unique architecture reminiscent of a Greek temple. It was not until the first decades of the $21^{\text {st }}$ century that the architectural research and restoration works supplemented the historical

Evaldas Purlys — Leipalingio dvaro pastatu raida:

žvalgomuju architektūros tyrimu ir restauravimo duomenys 
data and allowed to understand the actual function of the surviving buildings and the essence of their planning structure. However, this restoration did not allow fully exposing all the characteristic elements of the architecture and construction of the buildings in situ, as they became redundant while adapting the buildings for the new needs. Due to that reason, this publication is a written record of the discovered but unrestored and unreconstructed elements, which is important in understanding the relation of authentic details and the new additions that appeared during the reconstruction of the surviving buildings of the former Leipalingis Manor. 